\title{
Encoded Weakening of the European Integration - The EU-specific Vectors of Disorientegration $^{1}$
}

\section{Az európai integráció kódolt gyengülése - A dezorientálódás EU-specifikus vektorai}

The paper attempts to contribute to the better understanding of how the centrifugal force towards weakening European integration has developed by identifying the EU-specific vectors of such gradient. We argue that disorientegration is an echo effect of a complex amalgam of mutually intertwined and interrelated mechanisms embedded secularly into our European integration process. The paper also addresses whether secular stagnation adds to that centrifugal force. The paper finally outlines at least six potential principles of reversing the European disorientegration by cultivating contingency governance.

JEL codes: $\mathrm{E} 10, \mathrm{E} 60, \mathrm{~F} 15, \mathrm{H} 10, \mathrm{H} 70, \mathrm{O} 10$

Keywords: EU, integration, orientation, innovation, system, governance

Jelen írás az európai integráció megtorpanni látszó folyamata mögött munkálkodó EU-specifikus vektorokat igyekszik felfejteni. Bemutatja, hogy az irányvesztett és gyengülő integráció (dezorientegráció) voltaképp nem más, mint az integrációs folyamatba tartósan beágyazódó komplex és összefonódó mechanizmusok visszhanghatása. Túl azon, hogy a vázolt mechanizmusokkal összefüggésben a tanulmány

Olivér Kovács is a Senior Research Fellow at the University of Public Service Department of Economics and International Economics; Senior Research Fellow at the ICEG European Center.

Kovács Olivér a Nemzeti Közszolgálati Egyetem Közgadaságtudományi és Nemzetközi Közgadaságtan Tanszék vezető kutatói munkatársa; az ICEG Európai Központ vezető kutatói munkatársa. E-mail: Kovacs.Oliver.Istvan@uni-nke.hu

The work was created in commission of the National University of Public Service under the priority project PACSDOP-2.1.2-CCHOP-15-2016-00001 entitled "Public Service Development Establishing Good Governance" in the Ludovika Research Group. 
megvilágítja az úgynevezett szekuláris stagnálás szerepét is, fölvázol hat olyan alapelvet is, amelyre építô európai gazdasági kormányzás talán sikerrel fordíthatná meg a dezorientegrálódást.

JEL-kódok: E10, E60, F15, H10, H70, O10

Kulcsszavak: EU, integráció, orientáció, innováció, rendszer, kormányzás

\section{Introduction}

After a long period of reticence, economists in various internationally renowned institutions are drifting towards some sort of delusion of grandeur in terms of publishing evermore optimistic economic outlooks in the developed world including the European Union (EU). Indeed, it seems that the year 2017 was by far the best since 2011 and forecasts started to be continuously upwardly updated for the years to come due to unusually good growth conditions (for example, in 2017, the growth rate of the Euro area was 2.4 per cent, while it was 1.8 per cent in Japan and 2.3 per cent in the U.S.). Unfortunately, the Covid-19 pandemic, a topic not being incorporated in this study, hit in and the positive expectations have dissolved into the air quite rapidly.

Still, some moderation is in order even in the case of the EU owing to different systemic risks such as 1 . the looming global trade war(s) between Washington and Beijing affecting the European economy as well; 2. cumbersome completion of the EU single market due to outlining East-West EU splits together with Brexit (that is, Germany treats complex economic relations with the U.K. and will be affected negatively by Brexit, so as the Central and Eastern European member states via the German situation); and last but not least, 3. populism and Euroscepticism with a habit of springing back again and again (for example, by the Summer of 2018, the Italian coalition government earmarked with right-wing populism was set up; the Spanish prime minister was forced out after losing the no-confidence vote as an end result of the so-called Gürtel-corruption scandal); and last but not at all least 4. governmental intentions and end results are not necessarily the same, as Milton Friedman (1977) illustrated, so the governance and the effectiveness of policies face huge challenges in our complex socio-economic innovation ecosystem (for example, in 2018, the EU still has not achieved the aim of the Lisbon Agenda to make the EU the most dynamic and competitive knowledge-based economy in the world even though this was planned to be fulfilled by $2010^{2}$ ). Thus, risks and challenges are here to stay in the EU, which still has the potential to continue its secular disorientegration manifesting in loosing orientation and weakening integration.

European Commission (2018) emphasises that the EU should invest much more in the creation of the most innovative knowledge-based economy by being more ambitious in supporting breakthrough innovation. 
The present paper addresses the question of what are the main EU-specific mechanisms behind the secular 'disorientegration' of the European Union. With the deciphered vectors that are strongly intertwined and are creating ambiguous situations, the encoded disorientegrative centrifugal trend is revealed. In addition, we also argue that the secular stagnation phenomena add to such disorientegrative trend in Europe via rising additional policy related uncertainties. Finally, some potential principles are formulated relevant for governance working on reversing such disorientegrative trend.

\section{EU-specific vectors of disorientegration}

The following aspects and their dynamic configuration are taken into account: 1 . disorientegrational conditions as a result of EU enlargement (that is, differences in various dimensions); 2. internal processes within the EU in which the outlined differences appear; 3. external processes forming common challenges. All of the following aspects are strongly interlinked and intertwined and create ambiguous situations.

\subsection{Disorientegrational conditions given by EU enlargement}

It has been long recognised with regard to complex systems that one can never map and know with full certainty what the beginning conditions were, and even tiny differences in the conditions at the beginning can result in large non-linear changes and instabilities later on. EU enlargements have gradually encoded evermore instability into the European integration process due to the differences manifesting in: 1 . the levels of economic development of countries; and 2. cultural backgrounds as well as mental attitudes of countries.

As far as the disparities between already in and accession countries in economic development levels are concerned, integration-theorists have a predilection to consider the differing beginning economic conditions as one of the singular point of references when explaining the causes of later shortcomings of the integration (for example, problems of EMU). As it is discernible on Figure 1, along the course of enlargements, the gap between the average development levels of already in and accession countries measured in GDP per capita was growing except the occasion of the $4^{\text {th }}$ enlargement which also encoded even more gaping gap later on (for example, accession countries reached the average development levels of already in countries along the seven enlargements as follows: 76 per cent, 52 per cent, 41 per cent, 113 per cent, 40 per cent, 19 per cent, and 39 per cent, respectively). 


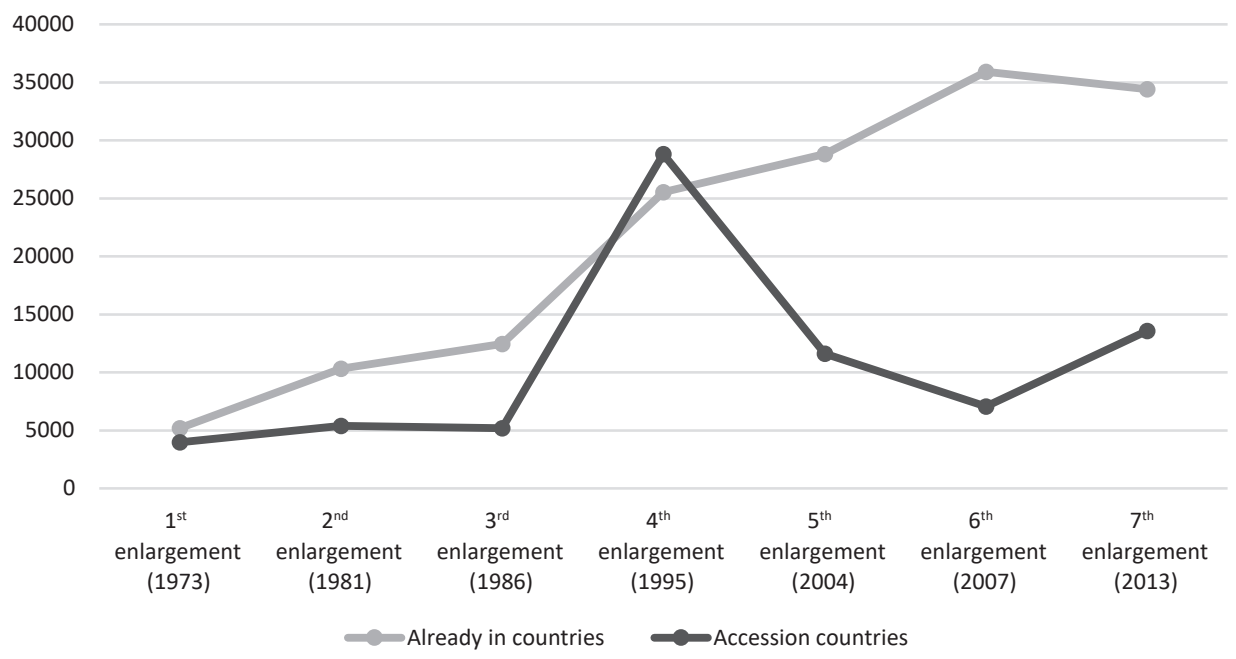

Figure 1

The economic development gap between already in and accession countries (\%, GDP per capita, current U.S.\$)

Source: Compiled by the author based on World Development Indicators, World Bank.

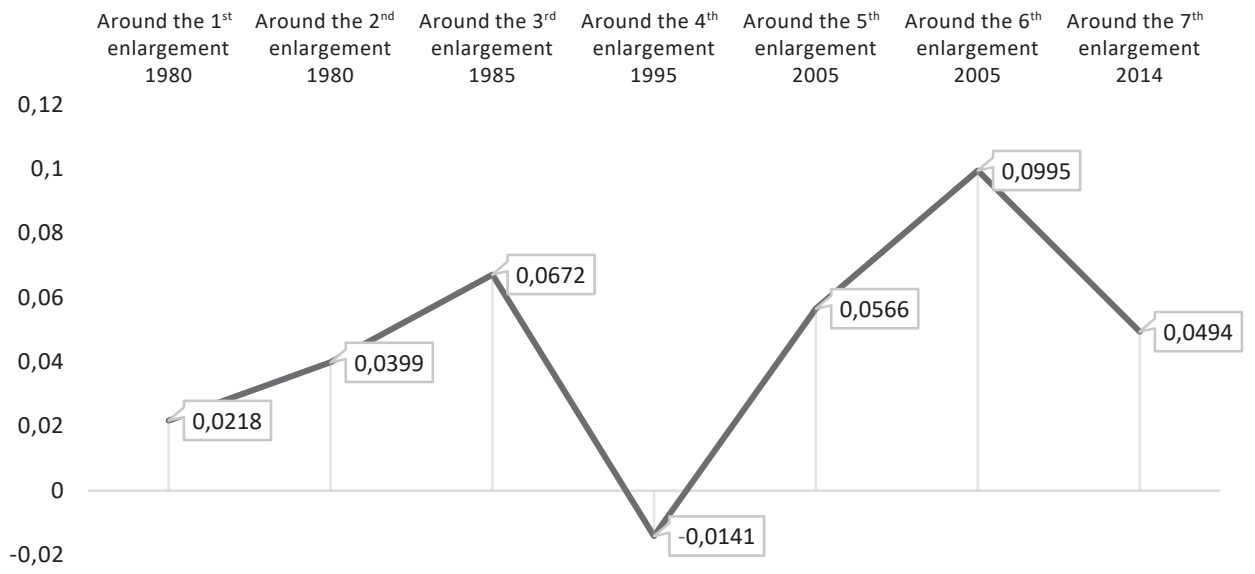

Figure 2

The human development gap between already in and accession countries (HDI)

Note: HDI is on a range from 0 to 1 . Due to the lack of data, the following years were used to cover enlargement periods: 1980 ( $1^{\text {st }}$ and $2^{\text {nd }}$ enlargements), 1985 ( $3^{\text {rd }}$ and $4^{\text {th }}$ enlargements), 2005 ( $5^{\text {th }}$ and $6^{\text {th }}$ enlargements), and 2014 for the Croatian accession. Source: Compiled by the author based on data of the United Nations Development Programme, Human Development Reports. 
If one looks at the average discrepancies in Human Development Index (HDI) ${ }^{3}$ along the enlargement process between already in and accession countries, it can be stressed that relatively huge average differences were prevalent except the $1^{\text {st }}$ and $4^{\text {th }}$ enlargements (Figure 2).

Despite the unimpeachable and well-documented fact on disparities (Seers et al. 1979, 1980, 1982; Magone et al. 2016), we argue that the culprit was also related to the lack of internal national commitment to stimulate structural change in line with the requirements of sustainable growth and development after the accession. Further enlargements limited the space for further integration, in other words, European integration was again and again diluted but not firmly deepened. In some cases, with accession (including the access to the European Structural and Investment Funds) funds proved to be benevolent auxiliary instruments to enlightened national public policy geared towards structural change (for example, shifting to knowledge economy in Denmark, Finland). In other cases, the European Union's essential promise has become 'money' rather than the peaceful milieu being conducive to human flourishing and money was subjected to be absorbed and allocated inefficiently by malfunctioning institutions in some cases, hence contributing to the conversation of lower international competitiveness (for example, Portugal and Greece). ${ }^{4}$ It is hardly by chance that the particularly strong supporter of the Single Market were mostly the peripheral countries by the end of the 1980s (for example, Italy, Spain, Greece, Portugal and Ireland) and the support for further enlargement was to some extent evaporated in case of old member states by 2005..$^{5}$ Success after accession always depended and still relies on good governance with efficient institutional architecture embedded into the wider innovation ecosystem. An important implication is that addressing structural weaknesses at national levels cannot be bypassed even by creating fiscal federalism at EU level with its transfer system. ${ }^{6}$

3 HDI is a summary measure of average achievement in key dimensions of human development: a long and healthy life, being knowledgeable and have a decent standard of living. The HDI is the geometric mean of normalised indices for each of the three dimensions.

4 Finland could transform itself to be a competitive knowledge economy, while Portugal was mostly unable to orchestrate such change successfully because of a mixture of internal phenomena: state captured by welfare clientele led to excessive social and wage policy which offered a fertile ground for worsening productivity as well as income inequality levels over decades and unsustainable public finances. See O Kovács, Stabilitás és dinamizmus. Az innovatív fiskális politika alapjai [Stability and Dynamism. The Fundamentals of Innovative Fiscal Policy] (Budapest: Alinea, 2015), 312.

5 See European Commission, Eurobarometer No. 34, Public Opinion in the European Community (Brussels: European Commission, December 1990), 31. By 2005, the support for further enlargement increased only in Central and Eastern European Member States.

6 One must not forget the fact that even the theoretical and empirical literature on fiscal federalism conveys that national governance plays a key role in it, and this is the way the system offers 'laboratory' to elaborate better and more efficient policies in parallel via trial and error, that is, more innovation freedom over time. See E Ahmad and G Brosio (eds), Handbook of Fiscal Federalism (Cheltenham: Edward Elgar, 2006). Still, fiscal federalism as the highest form of decentralised fiscal governance has uncertainties over how does it affect economic growth and development (Baskaran et al., 'Fiscal Federalism, Decentralization and Economic Growth: A Meta-Analysis', Economic Inquiry 54, no 3 [2016]). It is now empirically justified that income inequality has been significantly rising since the 1970s even in Germany with its federal structure having the famous Finanzausgelich mechanism. See the book written by the president of the Deutsches Institut für Wirtschaftsforschung, M Fratzscher, Verteilungskampf. Warum Deutschland immer ungleicher wird (Hanser Verlag, 2016). 
Let us add immediately that the differences, at the same time, provided the magnetic force of further integration, while inertia was also observable in certain enlargements. The accession of Greece in 1981 was an extraordinarily glaring example of dominating political interest over economic rationale. Inertia in the $2^{\text {nd }}$ and $3^{\text {rd }}$ enlargements were encoded mainly because 1 . French had become committed to initiating the Greek accession in case of a democratic transition; 2. and, what is more, there was a threat of revitalising communistic ideas in Italy, Portugal and Spain in case of the potential rejection of Greece as the cradle of Periclean Democracy. As a result of such uncertainty, the European Community had to prefer their accession as a reward for democratisation, which was a value-congruent political decision. ${ }^{7}$ Still, by now and in the shadow of the present Eurozone crisis related to Greece, the Greek accession is widely considered a mistake, ${ }^{8}$ whereas more crucial causes arose later in time. ${ }^{9}$ This is because voters tend to evaluate a policy decision in retrospect on the basis whether it has led to 'good' or 'bad' outcomes instead of considering whether the given decision was rationale and logical on the basis of available information and knowledge in the given historical context when the decision was made. This also lends support to the impression that the disorientegration narrative is here in town.

As far as the differences in cultural backgrounds and mental attitudes of countries are concerned, beyond the trivial and usual suspect (for example, linguistic difference which explains the most the less than expected labour mobility within the $\mathrm{EU}^{10}$ ), one must recognise that the harmony criteria between formal (laws, regulation, constitution and so on) and informal (norms, culture and so on) institutions does not only apply on national level to enhance growth and socio-economic development, but also on supranational

Spain had submitted its application to the European Community already in 1970; however, it did not receive an answer for a long period of time due to the existence of undemocratic governmental institutions in Spain. It demanded the accession again in 1977. After lengthy bargaining and discussions, the Treaty of Accession was signed only in 1985. On the threat of communist comeback, see D Seers, 'Introduction: The Second Enlargement in Historical Perspective', in The Second Enlargement of the EEC - Integration of Unequal Partners, ed. by D Seers and C V Vaitsos (Palgrave Macmillan, 1982), 6-7.

$8 \quad$ For a long time, studies on evaluating the costs and benefits of EU enlargements accentuated that enlargements were more or less beneficial for core, more developed countries - even for the U.K., see N Crafts, West European Economic Integration since 1950: Implications for Trade and Income. The University of Warwick, Working Paper No. 219, 2015 - while they were more costly for poorer, peripheral countries who absorbed enormous amount of EU Funds over decades (for example, S Ederveen, H de Groot and R Nahuis, 'Fertile Soil for Structural Funds? A Panel Data Analysis of the Conditional Effectiveness of European Cohesion Policy', Kyklos 59, no 1 [2006], 17-42). Still, funds supported the catching up process especially in case of Spain and Portugal (OECD, 'Is Convergence a Spontaneous Process? The Experience of Spain, Portugal and Greece', OECD Economic Studies no 16, Spring 1991). Recent studies emphasise that EU membership have significantly outweighed the costs except the case of Greece, see for instance Campos et al., 'Economic Growth and Political Integration: Estimating the Benefits from Membership in the European Union Using the Synthetic Counterfactuals Method'. IZA Discussion Paper no 8162, 2014.

9 For a systemic and comprehensive account on the Greek development with EU funds see Liargovas et al., Beyond "Absorption": The Impact of EU Structural Funds on Greece (Konrad Adenauer Stiftung, 2015), 142.

10 See L Andor, Labour Mobility in the EU: Challenges and Perspectives for a Genuine European Labour Market. Lecture at the European University Institute, Firenze, 24 June 2014; A S Chakrabarti and A Sengupta, 'Economic Incentives versus Institutional Frictions: Explaining Cross-country Labour Immobility in the European Union', 2015. 
level in supporting sustainable European integration. The presence of this harmony would mean that EU integration has national politics not biased extremely towards the aim at evading the violation of their country's cultural norms. With the lack of political union, this is only a phantasmagoria in the context of the EU and, as Guiso et al. (2016) demonstrate, the development of efficient policies along the interaction of countries can fall short and get impaired. EU countries greatly vary across institutional quality (Figure 3). Countries with higher institutional quality appear to be less reliant on other EU countries in terms of product export (for example, Finland, Sweden, Germany and so on) because they are typically more innovative and have deeper embeddedness into the global economy. Group 2 countries tend to bear harmony between formal and informal institutions in a more vigorous way. As Figure 4 depicts, lower institutional quality is mainly associated with lower economic integration in case of Mediterranean peripheral countries (for example, Portugal, Greece, Italy and so on) having structural backlog (that is, low share of technology driven industries, high share of labour intensive industries as Aiginger $(2013,42)$ underscored $).{ }^{11}$

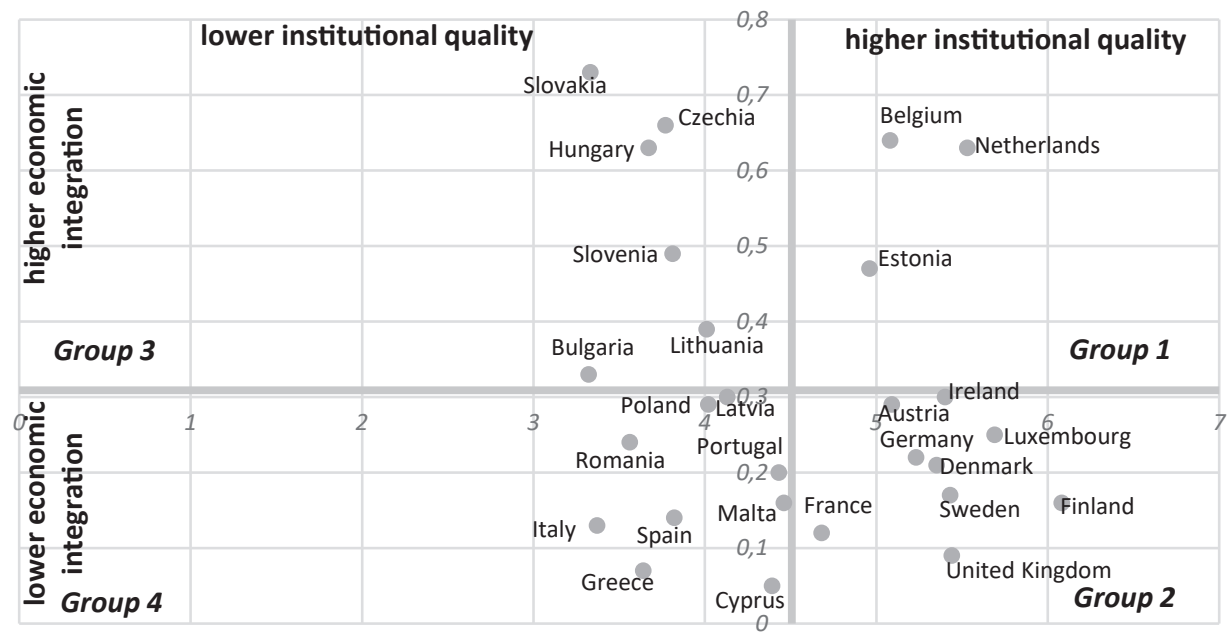

Figure 3

Institutional quality and export-based economic integration

Note: The horizontal axis refers to the score of countries in institutional quality derived from the World Economic Forum, Global Competitiveness Yearbook 2014-2015. The vertical axis refers to the degree of economic integration in terms of export to EU countries in percentage of GDP. The intersection represents the averages of the two indicators.

Source: World Economic Forum, Global Competitiveness Yearbook 2014-2015, Eurostat.

11 Economic growth of Greece (and together with that the possibility of reducing the debt ratio) is mainly based on sectors (tourism, catering trade) whose international competitiveness can be considered low (even compared to other periphery countries, for example, Spain). See World Economic Forum, Travel and Tourism Competitiveness Report 2015. Greece is only the $31^{\text {st }}$ among the 141 countries in the ranking, while Spain is the $1^{\text {st }}$, Italy is the $8^{\text {th }}$ and Portugal is the $15^{\text {th }}$. Online: http://reports.weforum. org/travel-and-tourism-competitiveness-report-2015/ 
Another equally important aspect of informal institutional differences is the cross-cultural psychology culture. For instance, let us take the degree of individualism and that of collectivism within the cultural matrices of countries. In this respect, Gorodnichenko and Roland (2012) found a strong causal link from individualism to innovation and long run growth. It is not surprising that Group 1 and Group 2 countries have higher average scores on individualism compared to Group 3 and Group 4 (the averages are as follows: $71,69,51$ and 51 respectively). ${ }^{12}$ This cleavage seems to be able to encode instability into the European integration process simply because more collectivist countries are likely to prefer the unsustainable extension of welfare states - as the cases of Portugal and Greece have shown - which, in turn, can ultimately stifle grassroots innovation. Bearing in mind that the degree of individualism might also be a good proxy of the propensity of people to act in solidarity (that is, to take sacrifices at the benefit of others in the EU in time of crises via cooperation), from a broader perspective, technological development induced individualism ${ }^{13}$ can result in higher focus on status-seeking at the expense of caring relationships (collaborations), which is equivalent with a trend towards more intergovernmentalism rather than to cooperation in creating federalist institutional architecture in the context of the European Union. This can even shed light on such disorientegrational force like the United Kingdome's vote in June 2016 to leave the EU, which traditionally shows one of the highest degrees of individualism. Disorientation thus appears to be a culturally strongly influenced phenomenon in the European integration.

\subsection{Internal processes within the EU in which the outlined differences appear}

The indicated different conditions with, of course, a variety of national interests along the course of deepening and widening led to more and more conspicuous differentiations especially since the 1990s. ${ }^{14}$ The most obvious examples of such differentiations were mirrored in 1. the Schengen Area; 2. and the Eurozone architecture. Albeit, differentiation was necessary and inevitable to accommodate the increasing heterogeneity with enlargements; differentiation created side-effects that have been developing in commonly unnoticed increments by manifesting the so-called 'creeping normalcy' for

12 These are the Hofstede scores of individualism. Individualism is defined as a preference for a loosely-knit social framework in which individuals are expected to take care of only themselves and their immediate families. Online: https://geert-hofstede.com

13 A paper by Snower and Bosworth (2016) demonstrates how technological development (for example, ICT gives rise to flexible work pattern, increasing focus on individualistic traits and so on) induces more individualism which also has negative impetus on societal welfare in the form of decreasing caring activities.

14 For instance, differentiation can be captured by looking at treaty articles. Schimmelfennig and Winzen (2016) pointed out that such differentiation became more visible since the 1990s. While differentiation in treaty articles was infinitesimally law in the enlargements of the 1970s and 1980s, its level rose with further enlargements (especially with the accession of Central and Eastern European countries). 
a relatively long period of time, up to the 2008 financial and economic turmoil, the ensuing Eurozone crisis and migration as well as refugee crisis.

Concerning the Schengen Area which reifies the free movement of people within the EU, the Agreement came into force in 1995 and now 22 out of 28 EU Member States are involved in it together with the following participating countries Iceland, Lichtenstein, Norway and Switzerland. By eliminating internal border controls and providing passport-free movement of people along the series of enlargements, on the one hand, and by having ineffective external border control management on the other hand, the European integration encoded negative side effects of Schengen as well. These side-effects have occurred dynamically on at least two fronts: 1. increasing tensions about immigration; 2. and controversial understanding over the costs and benefits of EU-migrants.

As for the rising tensions about immigration are concerned, one can assert that the social integration of immigrants has been beset with pressing difficulties. First, generations of immigrants could not effectively be integrated into the European societies by contributing to the co-existence of communities along ethnic and religious lines. The prime example of this was the French riots of 2005 that proved what was officially admitted later on by high-level representatives of the republic: the soft integration à la française failed. ${ }^{15}$ This was a clear harbinger of the evolvement of critical instabilities through secessionism in core and northern European countries. By now, riots have become a European phenomenon. ${ }^{16}$ Second, with the Eastern enlargement core countries became an important attractor of Romanian and Bulgarian Romani by vitiating the local support of the EU. This led to effective tensions and acts. For example, the series of fierce confrontations between Romani and French police in 2010 resulted in a divisive Presidential decision which called for spectacular expulsion of Romani people from France and the demolition of illegal Roma camps. Since 2008, similar crackdowns occurred in Italy on illegal immigrants, mostly Roma people from Romania being responsible for increasing crime. As a corollary, voices were echoed over creating more stringent policies on immigration by refining the Schengen Agreement. In 2011, Italy and France called for a strict review of the Agreement in fearing the influx of North African refugees. Of course, these types of claims for a stricter Agreement referred to a temporary (short time) intervention by not reversing the integration process (for example, France initiated border control after the 2005 London tube bombings, Portugal did the same during the Euro 2004 tournament). But, the erosion of Schengen has come to the forefront in a more dedicated way, on the one hand, with the enormous inflow of third country immigrants since the crisis in Syria and conflict elsewhere triggered approximately 1.8 million irregular border crossings at Europe's external borders in 2015 alone. ${ }^{17}$ On the other hand, terrorist attacks (in 2015: Paris; and on the Paris to Amsterdam express; in 2016: Brussels; truck attack in Nice, France; Christmas market attack in Berlin; in

\footnotetext{
15 M Moran and D Waddington, 'France in Flames: The French Riots of 2005', in Riots. An International Comparison, ed. by M Moran and D Waddington (Palgrave Macmillan - Springer, 2016), 39-65.

16 Riots also spread to other countries like Sweden and Germany afterwards. By 2016, several exclusion areas, that is to say 'no-go zones', have been formed in Sweden where the riots erupted have also proved the poor integration of immigrants.

17 European Commission, Stronger and Smarter Information Systems for Borders and Security. Brussels: European Commission, 6.4.2016. COM(2016) 205 final.
} 
2017: Manchester Arena bombing; bridge attack in London; attacks in Barcelona) righteously rekindled the need to revise and tighten the Schengen Agreement by bearing in mind that suburban riots can offer a fertile ground for terrorists. With the request for elaborating further the Schengen Agreement by keeping abreast of our gloomy times due to unsustainable immigrant patterns and imminent security issues, and all the more with the effective practice of some Schengen area states of reintroducing border controls ${ }^{18}$ and even extending them, ${ }^{19}$ it not only casts shadows on the future of the Schengen Agreement, but also illustrates that the compass of the EU integration points to disorientegration.

This tendency was partly fuelled by uncertainty over the socio-economic costs and benefits of EU-migrants leading to increasing negative perceptions over immigration in general throughout Europe. On the one hand, numerous studies have tried to measure the economic impact (financial dimension) of EU-migrants on native people and the economy as a whole in the host country by emphasising that immigrants can be net contributors to the host country's wealth-enhancement. ${ }^{20}$ On the other hand, the picture tends to be blurred once the spectrum of measurement is widened by taking into account political, social, cultural, humanitarian, and all other sorts of benefits and costs. Consequently, the perceptions on immigration have been more or less negative throughout the EU which culminates in '[...] the negative cycle of hostility towards migration'. ${ }^{21}$ For example, seductive and often pejorative terminologies used in media (bogus asylum seekers, welfare tourism, welfare scroungers) and the way the media portrays the migration issue exert to a large extent influence on public perceptions. Jacomella (2010) sensitively documented that press narrative plays a crucial role in forming public perceptions in Italy, Germany and the United Kingdom. Moreover, by surveying 33 developing and developed countries (including for example Belgium, France, Germany, Italy and the United Kingdom) on misperceptions about migration, IPSOS showed that citizens generally overestimate the share of immigrants in their respective countries (for example, the average guess of citizens surveyed in Germany

18 In June 2018, Germany and Austria started to join their police forces to stop illegal migration.

19 The Special Eurobarometer of the European Parliament conducted in April 2016 revealed that 66 per cent of the surveyed citizens of 28 EU Member States consider the EU action to be insufficient and 74 per cent would like to see the EU take more action. Or on the protection of external borders, 61 per cent consider the EU action to be insufficient and 71 per cent would like to see the EU take more action. See www. europarl.europa.eu/atyourservice/en/20160623PVL00111/Europeans-in-2016-Perceptions-and-expectations-fight-against-terrorism-and-radicalisation. On how the current circumstances cast shadow on Schengen, see the Report of the European Commission against Racism and Intolerance, ECRI (2016). Additionally, the proposed draft EU budget for 2017 submitted by the European Commission also aims at bettering the management of the EU's external borders and addressing the refugee challenges inside and outside the EU. See http://reliefweb.int/sites/reliefweb.int/files/resources/IP-16-2347_EN.pdf

20 In case of 20 OECD countries, see the economic benefits in Battisti et al. (2014). Dustmann and Frattini (2013) presented evidence that immigrants who arrived in the United Kingdom since 2000 have contributed far more in taxes than they have received in benefits. Portes (2015) refutes the assumption that migrants in the U.K. are likely to be welfare seeking by showing that migrants are underrepresented in benefit claimants. Foged and Peri (2015) showed that immigration had positive effects on native unskilled wages, employment and occupational mobility in Denmark between 2001 and 2008. BEPA, Migration and Public Perception. Bureau of European Policy Advisers (BEPA), European Commission, 09/10/2006, 4. 
and Belgium was more than two times higher than the actual shares). ${ }^{22}$ Apparently, as Amartya Sen pointed out, free and independent media takes part in the formation of values. ${ }^{23}$ Good governance and adequately working checks and balances together with impartial media are therefore the necessary preconditions of more realistic public perceptions over migration otherwise political populism and seductive press narrative can breed the concerns over insecurity as well as job losses into the feeling of the public. This in turn reinforces disorientegrational forces.

As far as the differentiation reflecting in the Eurozone architecture is concerned, it mainly manifested in a core-periphery context due to its inherent anomalies leading to sovereign debt crisis and ultimately to Eurozone crisis. By the creation of EMU in a unique way, that is, lifting the monetary policy at supranational level and leaving fiscal policies in the confines of national economic policy engineering, European policymakers have lost the general yardstick given by the experiences of long-lastingly performing monetary unions having fiscal unions, as well (for example, the United States, Canada and Switzerland). Without a fiscal union, we do not have the opportunity to enhance the EMU on the basis of other similar unions because they do not exist. Nevertheless, much attention has been devoted to investigate whether the EMU framework has affected positively or negatively the fiscal discipline of member states. Although the picture is mixed, the fundamental role of internal commitment to a prudent public finance without attributing significant role to the EMU rules ${ }^{24}$ is often underscored. Against this background, the EMU framework should have entailed rigorous fiscal adjustments and structural reforms for example in case of Greece or Portugal if for no other reason than that the exchange regime tool became no longer applicable at national levels. The reason why it did not happen can be found in the shortcomings of the EMU framework. What we have learnt from the history of monetary unions having fiscal unions at the same time is at least the fact that the 'no bail-out' clause should be stipulated and credibly pursued. ${ }^{25}$ Albeit the Maastricht Treaty seemingly guaranteed the 'no bail-out' rule on member state debts by the EU governance and the ECB, the credibility of this rule has perceptibly evaporated as the 2008 global crisis has summoned the techniques of providing rescue packages and purchasing sovereign debt of member states that are in extreme quagmire. This type of interventionism can be seen as a logical repercussion of not having a fiscal union. Historically, with a centralised and powerful fiscal policy the union is able to operate an effective transfer system which can provide a supportive hand in dampening problems arising at subnational governments affected more seriously. In the absence of a fiscal union and thus that of effective longer-run constraints, the propensity at member states level to run deficits and public debts was inherently encoded in the EMU framework. Put it differently, the phenomena of softening rules such as that of the Stability and Growth Pact (SGP) is often translated as a movement

\footnotetext{
22 See the survey www.ipsos-mori.com/Assets/Docs/Polls/ipsos-perils-of-perception-charts-2015.pdf

$23 \quad$ A Sen, The Idea of Justice (London: Penguin Books, 2010), 336.

24 Beetsma et al., 'Budgeting versus Implementing Fiscal Policy in the EU', CEPR Discussion Papers no 7285 , 2009.

25 Bordo et al., 'A Fiscal Union for the Euro: Some Lessons from History', NBER Working Paper no 17380, 2011.
} 
towards a system offering an increased fiscal room for manoeuvre at national level. ${ }^{26}$ Let us recall to the fact that the SGP was incrementally softened since its establishment. ${ }^{27}$ Since the original intellectual backing of the SGP was linked to a proposal of Theo Weigel about a 'Stability Pact', and since the pact was softened up - at German and French requests - by incorporating the aspect of growth and leaving behind the mechanism of automatic sanctions, this tendency is clearly discernible. Not to mention the SGP's reform in 2005 that can also be assessed as a step toward higher flexibility. ${ }^{28}$ Due to these developments, SGP has to a large extent lost its role to be an external coercive power in forcing member states to resort to permanent fiscal adjustments and reforms in the interest of EMU rules. Moreover, more rules and sanctions added to the SGP will by no means make the pact more useful, simply because the former version of SGP with numerical rules has completely emptied. ${ }^{29}$

Apart from the fact that softening the SGP was equal with the worsening credibility, particularly by the early 2000s when two non-complying countries (Germany and France) were not sanctioned, this framework acted as a mechanism which was on the one hand benefiting for core-countries like Germany and France, and it was counter-incentive for countries like Portugal in implementing necessary fiscal adjustments and structural reforms. Since the indebtedness in southern Europe, helped by Germany and France, fostered their imports, a contrario, it also triggered the German exports; and thus this system appeared to be a desirable one. Nonetheless, the surplus cash stemming from the strengthening exports was being to a large extent re-allocated into the southern countries in form of loans. The reason why the EMU did not serve completely as an external enforcement framework is the fact that the German and French governments would have blocked the flow of increasingly risky loans to the peripheral countries, but their interest groups would not have left it without a word because this would have led to additional economic slowdown determined by a decline in demand and workforce layoffs. ${ }^{30}$ For this reason, the creditor countries were not interested in breaking up this status quo and therefore closed one of their eyes to the fiscal indiscipline of the periphery

26 M Bassetto and V Lepetyuk, 'Government Investment and the European Stability and Growth Pact', NBER Working Paper no 13200, 2007, 33-43.

27 It was sensitively illustrated by Fischer et al., '101 Proposals to Reform the Stability and Growth Pact. Why So Many? A Survey’. European Commission, Economic Papers no 267, 2006. For a quantitatively assessed SGP approach see P Monperrus-Veroni and F Saraceno, 'Reform of the Stability and Growth Pact: Reducing or Increasing the Nuisance?' Documents de Travail de l'OFCE no 1, 2005, who pointed out its shortcomings to trigger more fiscal discipline. For more on SGP's shortcomings see C Wyplosz, The Stability Pact Meets Its Fate. Paper prepared for the 'Euro 50 Group' Meeting, 27 November 2002; Buti et al., 'Revisiting the Stability and Growth Pact: Grand Design or Internal Adjustment?' CEPR Discussion Papers no 3692, 2003.

28 M Heipertz and A Verdun, Ruling Europe - The Politics of the Stability and Growth Pact (Cambridge: Cambridge University Press, 2010).

29 See F Caselli, 'Discussion of Mongelli and Wyplosz', 2008.

30 Considering the fact that the German economy underwent a relatively huge slowdown in 2000-2003 (according to Eurostat, the economic growth was 3.1 per cent in 2000, in contrast, by 2003 it was close to stagnation) would also be instructive in understanding that the scenario about blocking the above mentioned activity has a strong counter-incentive. Another perhaps equally telling momentum is the fact that the current account of all credited peripheral countries has deteriorated right after their accession into the euro area, except Germany whose current account deficit changed rapidly into an increasing surplus. 
for a relatively long time. The institutional and implementation related differentiation in EMU framework heightened the hedonic editing of other member states. It refers to a situation when people are to convince themselves about that their earlier failure does not really matter. ${ }^{31}$ Its precondition is the missing fear from fear. Having in mind the consequences of non-compliance which can easily direct toward the misguided feeling that non-complying the external rules does not really matter, hence fiscal deficit can soar. This hedonic editing phenomenon was also on the card by serving as a counter-incentive to be committed to stringent fiscal consolidations and structural reforms by encoding the weakening of the entire EU. ${ }^{32}$ The situation was worsening by the time the 2008 financial and economic crisis and its ensuing Eurozone debt crisis hit in. The inefficient fiscal and monetary stimuli, then the fiscal austerity programmes geared to curb unsustainable indebtedness have led to further erosion of trust in the EU as the economic performance has remained rather weak. ${ }^{33}$ Still, with the astonishing institutional and organisational innovations in the European economic governance (for example, introduction of sixpack and two-pack, the European Semester, the Fiscal Compact, the Euro Plus Pact and establishing the roadmap towards Banking Union) the shift from intergovernmental solutions towards EU-level approaches has gained a historical momentum.

\subsection{External processes forming common challenges}

As enlargements and deepening progressed, issues to be addressed and tackled have become more and more intertwined and opaque causing an intrinsic tendency towards non-decisions, endless discussions and dissents by planting the seeds of governance deficit at EU level in the perceptions of the wider European public. This was confirmed by the Special Eurobarometer of the European Parliament conducted in April 2016. According to the survey, Europeans feel that EU action is largely insufficient in most of the fifteen areas suggested to them, and that a massive majority of citizens would like the EU to intervene more than at present in these areas. The latter one contributed to the widely documented democratic deficit and, of course, EU scepticism.

Importantly, in addition to the volatile trust level in the EU given by the enlargement process, the crisis makes the case worse together with newly arising external challenging processes. Without attempting to be exhaustive, we just name a few such as the Russian-Ukrainian military conflict interspersed with the Annexation of Crimea;

$31 \quad$ Individuals tend to strategically manipulate their memory to feel less guilty. This was confirmed by experimental economics literature too, see K K Li, 'Asymmetric Memory Recall of Positive and Negative Events in Social Interactions', Experimental Economics 16, no 3 (2012), 248-262.

32 O Kovács, 'The Hungarian Agony over Eurozone Accession', in Core-periphery Relations in the European Union - Power and Conflict in a Dualist Political Economy, ed. by J M Magone, B Laffan and C Schweiger (Routledge, 2016), 231-250 illustrated it in case of Hungary.

33 Not to mention the current brewing storm over the unfolding Italian banking crisis since February 2016. 
conflicts in Libya and Syria triggering migration and refugee crises; ${ }^{34}$ increasing terrorism activity. What is extremely important is that external common challenges are also reinforcing and heightening internal challenges either like the exit-prone behaviour in more and more EU Member States such as the United Kingdom, the Netherlands, France, Sweden, and even in case of Germany, ${ }^{35}$ or like the emergence of not necessarily EU-conform (potentially anti-democratic) political behaviour in certain countries (for example, Hungary and Poland). ${ }^{36}$ The smouldering decay of trust in the EU and in the integration process is merely a justification of the empirical finding that recession and turbulent times hurt more than boom can help when it comes to evaluating subjective well-being, which in turn affects the attitudes towards the EU, as well. ${ }^{37}$

Eventually, one may lead to the conclusion that European integration has been losing orientation and facing weakening commitment to integration not only because of anomalies, as the prevailing literature suggests, but because of inbuilt long-term processes in the path of the integration. Disorientegration is an echo effect of a complex amalgam of mutually intertwined and interrelated mechanisms (general- and EU-specific vectors) embedded secularly into our European integration process. All of the described vectors, being strongly interlinked and intertwined, are endogenously forming a centrifugal force to disorientegration and creating ambiguous situations. In the following we address whether the so-called secular stagnation adds to that centrifugal force and why a more transformative and catalytic policy mix is needed.

\section{The role of secular stagnation in disorientegration}

A new stream of economic literature focuses on the issue of secular stagnation meaning the long-lasting withering productivity, thus that of innovation performance in

$34 \quad$ This new wave of movement of people was mainly encoded into our world as a result of the hegemonic battles between the U.S. and Russia even during the cold war and afterwards. As Sachs (2016) shows, their conflicts led to instable states prone to disintegration and triggering the fleeing mass of people. For example, for the U.S., the war in Syria is a continuation of the plan for global U.S. hegemony launched by Defense Secretary and Under Secretary at the Cold War's end. Tackling the migration crisis requires collective actions in the spirit of faith community not only in case of refugees but also in case of climate-change-related migrants. According to estimates, between 25 million to one billion people might be displaced by climate change up to 2050 (IOM, Migration, Environment and Climate Change: Assessing the Evidence. International Organisation for Migration, 2009, 43).

35 For the German case, see www.express.co.uk/news/world/684282/Germany-Eu-referendum-DexitBrexit-Angela-Merkel-european-union

36 Kornai (2015) documented the U-turn of Hungary thereby it has become a post-communist autocracy. Kovács (2016) called the system a Weberian plebiscitary leadership democracy which declared an economic freedom war against Brussels, against foreign multinationals by injecting additional uncertainties into the innovation ecosystem. In case of Poland, recent far-reaching changes to its legal and institutional framework directly threaten human rights and undermine the rule of law, as the report prepared by the Council of Europe (2016) shows.

37 See De Neve et al., 'The Asymmetric Experience of Positive and Negative Economic Growth: Global Evidence Using Subjective Well-Being Data', IZA Discussion Paper no 8914, 2015. 
the advanced world since the 1970s. ${ }^{38}$ Secular stagnation thus means the perceptible deceleration of growth engine of which main constituents do not seem to have so much contribution to growth compared to few decades ago. Importantly, secular stagnation is associated with increasing uncertainties - unknown risks driving the increasing propensity to save and the declining propensity to invest - leading to increasing instability of the socio-economic system. Even the spillover effects can be much larger in time of secular stagnation ${ }^{39}$ contributing to non-linear changes of uncertainties over the future. There is a growing body of evidence that increases in uncertainty; these are mainly associated with protracted negative impetus on economic activity. ${ }^{40}$ Increasing uncertainty undermines for instance the capacity of the state to fulfil its developmental function since the sustainability of the welfare state becomes questionable, hence it reinforces macroeconomic instability.

Omitting the role of secular stagnation from our analysis would be equal to joining the club of terribles simplificateurs who are inclined to apply merely a reductive vision of progress. At this point, one must address the issue whether secular stagnation might be a systemic feature of our complex socio-economic innovation-ecosystem by calling for new policy initiatives.

We argue that secular stagnation is likely to be an autochthon phenomenon in our new techno-economic paradigm having specific features directing towards lowering productivity (which, of course, is getting to be harder and harder to be measured). We can claim with reasonable certainty that the Lundvallian (2002) term of 'learning economy' is a resulting condition of the new techno-economic paradigm (ICT-based, service sector dominant) requiring higher skills and quality as well as permanent knowledge development. This new paradigm places innovation and its main barriers and drivers under a different light. As it was indicated by the European Commission (2011, 27), studying innovation in services is becoming more and more important as the world has now arrived at a new techno-economic paradigm, exhaustively described by Perez (2009). This concept converges on the thinking of Kondratieff (1935) and Rennstich (2002), who claim that, beginning with the Industrial Revolution in England at the very end of the $18^{\text {th }}$ century, the world economy has experienced technological revolutions every 40-60 years. Each technological revolution employs new or relatively new technologies via the method of smart combination. The new ICT-based techno-economic paradigm that emerged since

$38 \quad$ T Cowen, The Great Stagnation: How America Ate All The Low-Hanging Fruit of Modern History, Got Sick, and Will (Eventually) Feel Better (Dutton, 2011); R J Gordon, 'Is US Economic Growth Over? Faltering Innovation Confronts the Six Headwinds', CEPR Policy Insight no 63, 2012; C Teulings and R Baldwin (eds), Secular Stagnation: Facts, Causes and Cures (CEPR Press, 2014); B Eichengreen, 'Secular Stagnation - The Long View', American Economic Review 105, no 5 (2015), 66-70. Robert J Gordon emphasises that modern innovations are not so impressive and the information revolution does not seem to be so conducive to economic development and growth (measured in GDP per capita) compared to earlier waves of innovation, such as the internal combustion engine, electrification or the telephone. See Gordon, 'Is US Economic Growth Over?'.

39 Eggertsson et al., 'A Contagious Malady? Open Economy Dimensions of Secular Stagnation', NBER Working Paper no 22299, 2016.

$40 \quad$ Baker et al., 'Measuring the Economic Policy Uncertainty', Chicago Booth Research Paper no 13-02, 2013; Bachmann et al., 'Uncertainty and Economic Activity: Evidence from Business Survey Data', American Economic Journal: Macroeconomics 5, no 2 (2013), 217-249. 
the midst of the 1970s not only provoked profound changes in the production process, but also tailored them to a more service-oriented economy. ${ }^{41}$ What is especially important from our viewpoint is that, as services' dominance increases with the sophistication of services innovation, the labour productivity becomes significantly lower than in the manufacturing sector. Statistically, economy has to a large extent become weightless in the sense that the intangible assets (ideas, knowledge, social relations and so on), which are so cumbersome to measure, have started to dominate. ${ }^{42}$ Additionally, there is an observable correlation between the secularly (since the 1970s) rising political instability and declining economic performance in the advanced world (including the EU). And the declining economic performance corresponds with the increasing dominance of services sectors at the expense of manufacturing. ${ }^{43}$ As a corollary, increasing 'servitisation' of the innovation ecosystem (that is, the increasing importance of intangibles) entailed with lowering measurable productivity by engendering uncertainties over the effectiveness of policies and governance both at national and EU level as well. This is not primarily positively conducive to the ethos of the EU integration. ${ }^{44}$

One should also bear in mind that the new techno-economic paradigm offers more qualitative outcomes that are harder to be measured adequately in numerical terms. Although inputs to innovation, by almost every measure, have been rising significantly over the past century, output, as measured by the trend growth rate of multifactor productivity, has been flat. ${ }^{45}$ Still, the added value of ICT revolution and its ongoing transformative power - together with nowadays innovations and R\&D activities - result in a more qualitative impact; this is missing from aggregate statistics like GDP per capita and its derivatives like productivity. ${ }^{46}$ Without a paradigm shift in our mindset which is fiendishly and exclusively concentrating on the quantifiable aspects of our progress, a self-reinforcing disorientegrative cycle seems to be appearing in Europe. Our current mindset indicates that the problem is not the lack of policies tailored to increase welfare and competitiveness, but their effectiveness and achievements seem

$41 \quad$ Around 67 per cent of global value-added is in services in the developed and developing economies (see World Bank data). In terms of employment, only the service sector has exhibited a permanent rise since 1999, reaching 70 per cent of total employment in the EU in 2009 (European Commission, 2010).

42 See J Haskel and S Westlake, Capitalism without Capital. The Rise of the Intangible Economy (Princeton \& Oxford: Princeton University Press, 2018).

$43 \quad$ See Brady (2016) on globalisation and political instability.

44 Credit consumerism is here, especially in Italy where the share of non-performing loans has been growing the fastest pace by calling for ECB's intervention in a form of buying those assets. Nevertheless, the demand side of the economy, to pull a healthier borrowing from banks to SMEs and households, still remains unresolved in a country having two lost decades in terms of productivity (innovation).

45 E Brynjolfsson, 'ICT, Innovation and the e-economy', European Investment Bank, EIB Papers 16, no 2 (2011), 60-76.

46 This paradigm is mainly dominated by services (as well as 'servitisation of products') that improve primarily the quality of life rather than promise a large productivity stimulator effect in a classical way as happened in the product sector decades before. Consequently, measuring productivity and GDP via a traditional methodology does not fully capture the well-being enhancing mechanisms of today's innovations in the advanced world, hence the impression about a downward trend in the growth of productivity is heightened. See unmeasured data-driven consumption in Mandel (2012), the non-measured part of our life in Mokyr (2014), and the limits of GDP (for example, as ironically called Gross Deceptive Product) and productivity to capture welfare in Aeppel (2015). 
to be questionable and inappropriate since long-term decline in productivity growth and innovativeness is observable. ${ }^{47}$ It fuels policy uncertainty which reduces innovation/ investment activity. As the Nobel Laureate Michael Spence argued, political instability undermines the evolvement of comprehensive, responsive and coherent economic-policy agenda. ${ }^{48}$ The resulting mixture of mostly consumption-driven low growth, high unemployment and rising inequality aggravates further political instability and fragmentation, which makes the officials' capacity to implement effective economic policies more cumbrous.

Finally, it is worth noting that the slowdown of productivity was more abrupt in Europe than for example in the U.S., however. ${ }^{49}$ It sheds light at least on two things. First, the U.S. complex innovation ecosystem has been performing relatively better compared to Europe. Second, the European aspect of secular stagnation implies that some doubts are in order regarding the effectiveness of economic policy in the past decades. For instance, despite the overregulation and excessive taxation, the European Union seems to have been falling short in decreasing the poverty and social exclusion since the approval of its Europe2020 strategy. Nowadays, approximately 6.9 million people are deeply poor in the European Union (living on $\$ 4$ a day or less) which is nearly the population of Sweden and Ireland combined or the population of Bulgaria alone. ${ }^{50}$ Between 2008 and 2014, the number of people at risk of poverty or social exclusion has grown by 6 million, a trend being diametrically against the target of Europe2020 to lifting at least 20 million people out of poverty and social exclusion by 2020 compared with 2008 . It points to the pronounced impoverishment the EU has been facing today which undermines trust and confidence and offers ground for nationalism, EU scepticism. ${ }^{51}$ Evidence suggests that Europe needs to find a new form of growth as the Whitworth cannon of poverty eradication as well. This means that more transformative and catalytic policies are required to meet technological and socio-economic missions due to the fact that our world economy has become ever more complex, hence the explanatory power

$47 \quad$ Halmai (2017) also raised the question: "Is it possible to have an efficient economic policy coordination in the current context?” (P Halmai, “Új geometria: „teljes” gazdasági és monetáris unió? A gazdasági kormányzás új dimenziói az Európai Unióban', Magyar Tudomány 178, no 1 (2017), 15.

48 M Spence and D W Brady, 'Economics in a Time of Political Instability', Project Syndicate, 23 March 2016.

49 N Crafts and G Toniolo, 'Aggregate Growth, 1950-2005', in The Cambridge Economic History of Modern Europe: 1870 to the Present, Volume 2, ed. by S Broadberry and K H O’Rourke (Cambridge: Cambridge University Press, 2010), 296-332.

50 Data stem from the World Bank.

51 See Eurostat, Smarter, Greener, More Inclusive? Indicators to Support the Europe2020 Strategy (Eurostat, Statistical Books, 2016), 9. In the spirit of 'always look on the bright side of life', the European sluggishness in terms of innovation has its own merit. As the World Inequality Report 2018, prepared by the World Inequality Lab revealed, income inequality has been rising both in Western Europe and the United States. Still, the European rise has been much smaller compared to that of the U.S. Europe and the United States had similar levels of inequality in 1980. While the top 1 per cent income share was close to 10 per cent in both regions in 1980, it increased merely up to 12 per cent in 2016 in Western Europe, while the U.S. share became 20 per cent. Consequently, albeit the European innovation system has been spectacularly outperformed by the U.S., the European continent has been experiencing a lower level of worsening inequalities.

Európai Tükör 2021/1. 
of our theories and earlier empiricism have become strongly worn. ${ }^{52}$ All in all, secular stagnation phenomena add to the increasing disorientegrative force in Europe via rising additional policy related uncertainties.

\section{Conclusions}

In this contribution we have deciphered the dynamic configuration of processes lurking behind the European disorientegration phenomena. Despite the consensual rhetoric on disorientegration which handles it as a relatively new-fangled phenomenon, with a veneer of a complex approach, EU-specific vectors have been explored that play a key role in directing towards disorientegration. The EU-specific vectors (disorientegration conditions as a result of EU enlargement; internal processes within the EU in which the outlined differences appear; and external processes forming common challenges) are strongly intertwined and create ambiguous situations by forming a disorientegrative centrifugal trend. In addition, we have also underlined that the secular stagnation phenomena adds to such disorientegrative trend in Europe via rising additional policy related uncertainties.

To the extent that there is no common (EU-level) reaction, to such an extent differing national reactions to certain challenges are growing. And vice-versa, to the extent that national solutions emerge, to that extent there will be no common solution (collective action). This leads to a contingent situation by preserving and even worsening the EU's capability-expectations gap. Since the challenges of the EU make the socio-economic innovation ecosystem pervaded by a great deal of uncertainty, there is a need for a contingency aware governance to better coordinate between common tools in supporting resiliency (shock absorption, risk sharing) and incentive regimes such as the markets to foster fiscal and financial stability (risk reduction).

Bearing in mind the nature of the European integration, our paper can by no means offer the full panoply of policy perspectives to be considered by EU level governance and national leaders. Still, and beyond the usual suggestion of 'complete the internal market', our current paper conveys at least six intertwined and mutually reinforcing potential principles of reversing the European disorientegrative forces in a more detailed manner.

1. Festina lente: Since the European integration has weakened the democratic sovereignty of the member states by creating a chasm between far-reaching economic integration and limited political integration, the principle of festina lente (make haste slowly) is in order when it comes to further European integration (enlargement and deepening). Bearing in mind the complex set of issues behind secular disorientegration, the need for an ever-closer union is obvious but with meticulously considered steps that are a) rehabilitating the delicate balance between national and European level governance; and b) offering learning while doing and

52 Once the financial sector served the real economy, it is now a parasite of the real economy; previously, if employment expanded, average wages had risen or at least public revenues were increasing, and this trend cannot be identified today; once productivity increased, it was accompanied by wage growth, it is not necessarily true today (for example, just take a mere glimpse onto the case of the U.K. of which GDP grew during 2007 and 2015 while the real wages contracted perceptibly).

Európai Tükör 2021/1. 
positive psychic capital to gain continuous support for the European integration project.

2. Value-congruent governance - Fairness and equability: beyond the peace-holder role of the European integration, one of its main objectives is pursuing human well-being. Keeping in mind the current context, and the need to revive and strengthen interpersonal and institutional trust, Europe should do more to serve as a sanctuary of a more equitable distribution of economic prosperity if for no other reason than the political slogan of 'bolstering socially inclusive economic development' has now completely emptied. To this end, instead of completely eradicating all inequalities, contingency governance shall reconsider the paradigm of expanding the welfare state by refining its focus on widening the opportunities of individuals to excel in personal and professional developments (equability) in reducing the culture of entitlements and to fasten talent development for a more healthy innovation ecosystem. Putting fairness and equability onto the policy agenda can happen in many ways. For instance, fostering and supporting the evolution and diffusion of relevant movements like the Economy for the Common Good can be a great way forward pursuing integrity, responsiveness, fairness, and so on. Potential institutional instruments in that direction can be the pro-active cooperation among independent monetary and fiscal policy institutions and unbiased consulting experts with the aim at being a regulatory conscience by analysing inexorably the nexus between governmental measures/ policies and fairness/inequality.

3. Broadened complexity aware governance: Encoded disorientegration directs toward a governance which is not in denial vis-à-vis our complex innovation ecosystem characterised by uncertainty, non-linearity, unpredictability and emergence. Contingency governance has at least the following constituent sub-principles.

- Systemic thinking is a must: to address the dynamic configuration of processes related to disorientegration in the EU or secular stagnation as an endogenous phenomenon. For instance, by taking into account the features of our current ICT-based, services dominated techno-economic paradigm; or by incorporating the effects of planned policies and measures on inequality all the time (for example, how the Capital Markets Union will affect income and wealth inequalities in countries, and so on). ${ }^{53}$ In addition, establishing a parliamentary committee - in each Member States and in the European Parliament - for the future to initiate a dialogue on major future problems and opportunities in recognising important political themes at an early stage by outlining alternatives and different policy lines is of key interest as well (for example, regarding the impacts of radical technological change on democracy, on political structure, on many levels on human beings such as inequality and the future of work and so on).

As Alstadsæter et al. (2017) pinpointed, tax evasion for the rich is easier when they have access to advanced wealth concealment services whereby they are able to conceal assets and investment income abroad. An integrated Capital Markets Union will spark those services by potentially exacerbating inequalities in countries. 
- Acknowledge our limited knowledge and policy horizon: it credits Harry S Truman's words, namely that experts do not like to be seen to require any additional learning since it would be equal to admitting that they were previously not those experts the public can build on. In the era of immediacy, policy is expected to follow arousing tensions and a crisis in due time but it is impossible. Expecting adequate and one-shot policy solutions from national and EU-level governance to certain wicked problems is a naiveté highly resembling to the fatal conceit of Andrej Aleksandrovič Ždanov, the former soviet politician, who once ordered artists to create masterpieces. Consequently, there is no and will not be any buildable supermodel transferable to every Member State. Social learning ability still remains the stove of any socio-economic development by accepting that blossoming quantification can misguide and distort our evaluations over the effectiveness of various policies in tackling complex challenges and interpretations over socio-economic phenomenon. Contingency governance is therefore not to pursue quantophrenia, that is, the excessive reliance on hard numerical statistics, but to incorporate the qualitative aspects in a more vigorous way (for example, the effects of innovation in the public sector shall be primarily found in well-being enhancing qualitative aspects; when it comes to fostering inclusiveness, the concept to measure poverty shall be refined because of its shortcomings ${ }^{54}$ ). Moreover, quantophrenic behaviour can be a camouflage in the financial sector-real economy context as well in the sense that financial sector does not lend enough financial ammunition for those innovative ideas that are new, but are still initially raw and poorly understood. This way, a bias toward more quantified and well established ideas of older vintage exists; however, economic history exemplified that new and more risky ideas spur subsequent inventions more frequently. ${ }^{55}$

- Experimentalism and empowerment without chasing a utopia: such contingency government is, by its very nature, deliberately experimental and is to empower the citizens with the aim at accelerating mistakes and the learning process from them. Once the principle of festina lente is hold, shifting toward a more political union, toward a more federal-like system is more likely by offering more room for member states to learn from each other more quickly about policies and measures targeting the kick-start of productivity growth together with a socially more inclusive European knowledge-based economy

$54 \quad$ For instance, global poverty lines multiplied by PPP - a method the World Bank, the Sustainable Development Goals are using - do not capture the differences in the cost of living between cold and warm countries etc. The realistic standard error for global poverty can even be 200 million! See A Deaton and O Dupriez, 'Purchasing Power Parity Exchange Rates for the Global Poor', American Economic Journal: Applied Economics 3, no 2 (2011), 137-166.

55 Packalen and Bhattacharya (2015) illustrated that in case of the U.S. based on the text of nearly every U.S. patent granted during 1836-2010. The European R\&D statistics also lend support to the higher risk-aversion on the one hand, and the fiscal incapacity of national public finances to support R\&D\&I via fiscal incentives (as Eurostat (Eurostat, Europe 2020 Strategy. Positive Developments since 2008 in the EU on Education, Climate Change and Energy... but Limited or No Progress for Employment, Poverty and R\&D. Eurostat, News release 19 July 2016) shows, the R\&D target of the Europe2020 strategy has not been approached, the progress was more limited in the period 2008-2015). 
(for example, popular referendums, citizen initiatives, pursuing digital platforms as hybrids of direct democracy and representative democracy when it comes to forming and initiating government actions in a co-written way). This is the point where the cross-sectoral and cross-actor mindset must appear. Complexity-aware collaboration to share risk and responsibility is not primarily an option, but a coercive necessity in addressing complex challenges and to cultivate the evolvement of a European faith community via preserving some diversity to guarantee some unity. The impression about and the reality of limited discretionality, which is less likely to dismantle the trust infrastructure, can be safeguarded by building more on collaborative participatory mindset, especially in turbulent times pervaded by uncertainties. However, our complex system together with our limited understanding of it puts a question mark over the effectiveness of such participative governance which can easily become just a utopia. Albeit some argue that Europe needs more democracy, it might intensify disorientegration because there are no clear-cut answers and objective consensual opinions in the wider public over complex issues (for example, Brexit voting). For this reason, democratic deficit shall be mitigated via feeling the pulse of the citizen opinion without triggering negative impetus on governance and integration. For instance, the introduction of participatory budgeting in the digital age can be a good way forward as an antidote to right wings populism (that is, state captured by corrupted elite) and to dampen the discontent against globalisation (that is, participative budgeting means discussing budget-related issues with citizens on public service delivery when it comes to prioritising amongst different options). ${ }^{56}$

4. The vast majority comes first: EU governance must continuously demonstrate that it intends to act in the interest of the vast majority of EU Member States. The real socio-economic development throughout the becoming EU - that is, creating conditions for the realisation of human personality - rests upon our ability to stimulate synergies by influencing the dynamic relationship between core countries and peripheral ones. In this respect, two sub-principles are in order.

- Grounding differential diagnoses: establishing the culture of differential diagnoses in a more dedicated way in policymaking and crisis management across the EU (for example, fiscal consolidations with different functions in core and periphery countries) is of paramount importance. This might also dampen the culturally strongly influenced disorientegration in the EU. It would feed into

$56 \quad$ For example, participative budgeting influences prevailing priorities and re-configures the mindset of resource allocation according to the perceived and expressed needs. In numerous cases, it contributed to the process of placing customers' preferences into the forefront, since it resulted in non-negligible changes in the priorities followed by municipal government. Participatory budgeting can serve as a mechanism for improving the learning curve because of the potentially higher quality of feedback circle. See O Kovács, 'Policies Supporting Innovation in Public Service Provision', INNO-Grips Policy Brief no 5, 2012. What is more, participatory budgeting shall be embedded into a wider insurance scheme against lax fiscal governance and corruption (that is, in case of fiscal laxity or detected corruption, transfers shall be channelled from public administration towards value-congruent investments juxtaposed in a list to be selected via participatory mechanism as priority making, hence strengthening democracy). 
the increased experimentalism by acknowledging that no mere supranational governance mechanism featured with one-size-fits-all policies and programmes could address and solve the complex European disorientegration.

- Cultivating internal commitment: importantly, despite the unimpeachable and well-documented fact on disparities among already in and accession countries, the main culprit was predominantly related to the lack of internal national commitment to stimulate structural change in line with the requirements of sustainable growth and development after the accession. Success after accession always depended and still relies on good governance with efficient institutional architecture embedded into the wider innovation ecosystem. An important implication is that addressing structural weaknesses at national levels cannot be bypassed even by creating fiscal federalism at EU level with its transfer system. Ameliorated economic freedom as well as improving innovation ecosystem at national levels shall be paradoxically enforced more directly by supranational interventions. The task is to eliminate the almost entirely missing fear from fear (instabilities, imbalances, so, from deterring sanctions) in the Eurozone and in the entire European Union, as well (that is, imposing sanctions if needed in accordance with Article 126(8) of the Treaty on the Functioning of the European Union; winding up the illusion of cheap money - providing developing funds in a pulse basis rather than permanently(!); going beyond intergovernmentalism when needed, but pursuing no-bailout principle ${ }^{57}$ ).

5. Fostering competency, openness and future orientation in European governance: EU governance shall be competent and effective, and be able to select a viable sustained-growth strategy which includes the mentioned elements. In this regard, trust and confidence of EU citizens must be re-established and strengthened. It can be achieved through at least two sub-principles.

- Catalysing mission orientation to signal the ability of EU policy in reinvigorating growth: encoded disorientegration might also offer a game-changing opportunity. Growing uncertainty might lower the political costs of reforms - reforming not only the financial and fiscal, but that of the institutional architectures ${ }^{58}$ - because the voters are more likely to accept that the outcome starts to depend on the weaving relations of various external processes and not mainly (only) on the governmental actions. Therefore, higher uncertainty and greater macroeconomic volatility (recessionary periods with

$57 \quad$ As the Greek case illustrates, the key to the development of Greece can be the sobering, master role of integration, which has already started by the EU actually taking over the role of governance. ESM (European Stability Mechanism) means a fiscal puffer, but not for member states letting their public finances facing continuous indebtedness. This is in line with the recommendation of German Council of Economic Experts (2013) on Maastricht 2.0.

58 Recently, more and more studies and concept papers have been published on the future of Europe. With respect to the big issue of 'how' to reinvigorate the European integration see Bénassy-Quéré et al., 'Reconciling Risk Sharing with Market Discipline: A Constructive Approach to Euro Area Reform', CEPR Policy Insight no 91, 2018, while on the more intriguing questions of 'who' and 'when' to unlock synergetic integration see N Campos and J E Sturm (eds), Bretton Woods, Brussels and Beyond: Redesigning the Institutions of Europe (CEPR Press, 2018). 
grand challenges) can be conducive to brake the gravitational forces indicated earlier by making reforms to be politically more viable (for example, mission 1: harmonising the real economy and the financial sphere by fostering positive green finance to address unsustainable credit consumerism and consumption patterns to transform the economic model via breaking secular stagnation; mission 2: reducing the ever-widening gulf of inequality, while to take into account environmental constraints, and so on). Of course, it should be in tandem with regulation and monitoring of the financial/banking sector, ${ }^{59}$ and we should be modest in our hopes, as Blanchard (2013) put it.

- Increasing trust through better public services: enormous challenges associated with this autochthonously increasing fundamental uncertainty call for good governance and innovative public sector capable of signalling its ability to cope with the challenges by creating and maintaining necessary trust. Even though the Great Recession seems to be transmogrified into a slow and rather frail recovery, uncertainties and potential uncertainties have to be diminished by increasing the legitimacy of public intervention at national levels. This is in line with the festina lente principle described above that would consist of growth-friendly fiscal consolidations and public sector innovations (PSI). ${ }^{60}$ The public sector should serve as a demonstrator being in conjunction with an approach that cultivates innovation, and eventually tries to address as well as alleviate wicked problems. PSI can be regarded '[...] as the process of generating new ideas and implementing them to create value for society, covering new or improved processes and services'. ${ }^{61}$ PSI may help to maintain the quality of service provision, to reduce excessive expenditures while not imposing additional burdens on labour and the economy as a whole by fostering trust building in time when painful measures (for example, fiscal adjustments, structural reforms) are inevitable. PSI thus becomes a mechanism towards increasing the quality of governance across the board.

6. Live in details, think in details by building on complexity economics: since European disorientegration is a result of the interplay of complex global (and Europeanwide) and national (member states) vectors, a pious wish is not enough to frame and ground contingency governance. Governance cannot be based on generalities but on the continuous discovery and understanding of the reality in detail. Two sub-principles are arising in this respect.

- Progressing toward complexity economics: economics profession shall go beyond the practice of considering more complex phenomena as incidental addenda

59 For instance, in the spirit of the famous Latin question of 'Quis custodiet ipsos custodes?' [Who watches the watchmen?], the financial sector's regulation should refine the roles of monitoring/auditor companies being in monopoly position to take better care of their monitoring in fulfilling their original goals that were not considered particularly important before the 2008 financial crisis. On the role of auditors/accountants in the crisis see R Brooks, Bean Counters: The Triumph of the Accountants and How They Broke Capitalism (London: Atlantic Books, 2018).

60 For more on public sector innovation, see Kovács, 'Policies Supporting Innovation'.

61 European Commission, Powering European Public Sector Innovation: Towards A New Architecture (Report of the Expert Group on Public Sector Innovation, Directorate-General for Research and Innovation, 2013), 7. 
to economic engineering and theorising. This is the point where the cross-disciplinary mindset must appear. Contingency governance shall acknowledge the complexity of the socio-economic innovation ecosystem and the fact that policy outcomes are not mathematically described economic ones, but complex patterns. Complexity must be addressed since it forces economics and policymakers to be more humble by not condemning ambivalence. Without pursuing a complexity based economic approach, ${ }^{62}$ without acknowledging individual and system-wide interactions (at least most of them), European economic governance and its macroeconomics backing may indeed be doomed and policies tend to fall short in becoming the instruments of a sustainable development value-congruent governance and what any kind of governance will have is just a cacophony of ideas that are nothing more than a theatre of empty rhetoric.

- Refining approaches to education and skills: the current entire education concept is worth reconsidering and refocusing in the era of knowledge economy (emerging digital economy including the development of the new production revolution, that is to say, Industry 4.0) when learning and work become one and schools must be the voice of the future. Such approach can embrace not only a more pluralistic education system (including teaching of economics science at universities ${ }^{63}$ ) cultivating cross-sectoral, cross-actor and cross-disciplinary mindset, ${ }^{64}$ but also the more organic introduction of various techniques such as new and innovative peer-to-peer learning programmes without decisive curricula; tri-partite co-creation projects to addressing challenges rather than solving them once and for all; voucher-based systems, cooperation with the business sector to co-develop more pleasant work in an era of going digital and robotisation and so on. Since most people tend to believe that something is true or false, modern skills and complexity aware knowledge-based education may help in overcoming such reductionism by suggesting to people that pluralism and ambiguity are in order, hence they might get a more realistic picture about the difficulties of economic governance. In this way, the demand side of economic governance, that is to say, citizens might show higher level of tolerance against economic governance in an era of perplexingly intertwined complex challenges by feeding into increasing trust in the public sector and in contingency governance.

In the introduction we cited Milton Friedman, by paraphrasing his famous words; our work conveys that there is no such thing as free governance and value-free economics, either. In following our line of thinking, and more than 65 years after Friedman's essays

62 For a more detailed discussion on complexity economics, see O Kovács, 'Grounding Complexity Economics in Framing Modern Governance', Acta Oeconomica 69, no 4 (2018), 571-594.

63 See more in L Csaba, 'A 21. század a világ közgazdaságtanában', Köz-Gazdaság 13, no 2 (2018), 113-126.

64 In concordance with the messages of outstanding pedagogues like Paulo Freire (1970), who was a real proponent of an interactive education system which is to motivate critical thinking and curiosity, a way towards recognising complexity. His thinking is of high relevance today when all forms of increasing inequality is observable even in the developed world. 
on positive economics, ${ }^{65}$ it has become vital by now that the economics of contingency governance should be normative and value-based. And surely, we should be more modest in our hopes.

\section{References}

Aeppel, T, 'Silicon Valley Doesn't Believe US Productivity is Down'. Wall Street Journal, 16 July 2015.

Ahmad, E and G Brosio (eds), Handbook of Fiscal Federalism. Cheltenham: Edward Elgar, 2006. Online: https://doi.org/10.4337/9781847201515

Aiginger, K, 'A New Strategy for the European Periphery'. WIFO Working Papers no 443, 2013.

Akerlof, G A and R J Schiller, Animal Spirits: How Human Psychology Drives the Economy, and Why It Matters for Global Capitalism. Princeton: Princeton University Press, 2009.

Akerlof, G A and R J Shiller, Phishing for Phools: The Economics of Manipulation and Deception. Princeton: Princeton University Press, 2015. Online: https://doi.org/10.2307/j. ctvc777w8

Alesina, A and B Reich, 'Nation Building'. NBER Working Paper no 18839, 2013.

Alstadsæter, A, N Johannesen and G Zucman, 'Tax evasion and inequality'. NBER Working Paper no 23772, 2017. Online: https://doi.org/10.3386/w23772

Andor, L, Labour Mobility in the EU: Challenges and Perspectives for a Genuine European Labour Market. Lecture at the European University Institute, Firenze, 24 June 2014. Online: http://europa.eu/rapid/press-release_SPEECH-14-491_en.htm

Ang, A and F A Longstaff, 'Systemic Sovereign Credit Risk: Lessons from the U.S. and Europe’. Journal of Monetary Economics 60, no 5 (2013), 493-510. Online: https:// doi.org/10.1016/j.jmoneco.2013.04.009

Bachmann, R, S Elstner and E R Sims, 'Uncertainty and Economic Activity: Evidence from Business Survey Data'. American Economic Journal: Macroeconomics 5, no 2 (2013), 217-249. Online: https://doi.org/10.1257/mac.5.2.217

Baker, S R, N Bloom and S J Davis, 'Measuring the Economic Policy Uncertainty'. Chicago Booth Research Paper no 13-02, 2013. Online: https://doi.org/10.2139/ssrn. 2198490

Baldwin, R and F Giavazzi (eds), The Eurozone Crisis: A Consensus View of the Causes and a Few Possible Solutions. CEPR Press, 2015.

Battisti, M, G Felbermayr, G Peri and P Poutvaara, 'Immigration, Search, and Redistribution: A Quantitative Assessment of Native Welfare'. NBER Working Paper no 20131, 2014. Online: https://doi.org/10.3386/w20131

Bassetto, M and V Lepetyuk, 'Government Investment and the European Stability and Growth Pact'. NBER Working Paper no 13200, 2007, 33-43. Online: https://doi. $\operatorname{org} / 10.3386 / w 13200$

65 See M Friedman, Essays in Positive Economics (University of Chicago Press, 1953).

Európai Tükör 2021/1. 
Baskaran, T, L P Feld and J Schnellenbach, 'Fiscal Federalism, Decentralization and Economic Growth: A Meta-Analysis'. Economic Inquiry 54, no 3 (2016), 1445-1463. Online: https://doi.org/10.1111/ecin.12331

Bauer, M, C Blattman, J Chytilová, J Henrich, E Miguel and T Mitts, 'Can War Foster Cooperation?’ CEPR Discussion Paper no 11327, 2016. Online: https://doi.org/10. 3386/w22312

Bauer, M, A Cassar, J Chytilová and J Henrich, 'War's Enduring Effects on the Development of Egalitarian Motivations and In-Group Biases'. Psychological Science 25, no 1 (2014), 47-57. Online: https://doi.org/10.1177/0956797613493444

Beetsma, R, M Giuliodori and P Wierts, 'Budgeting versus Implementing Fiscal Policy in the EU'. CEPR Discussion Papers no 7285, 2009.

Bénassy-Quéré, A, M Brunnermeier, H Enderlein, E Farhi, M Fratzscher, C Fuest, P O Gourinchas, P Martin, J Pisani-Ferry, H Rey, I Schnabel, N Véron, B Weder di Mauro and J Zettelmeyer, 'Reconciling Risk Sharing with Market Discipline: A Constructive Approach to Euro Area Reform'. CEPR Policy Insight no 91, 2018.

BEPA, Migration and Public Perception. Bureau of European Policy Advisers (BEPA), European Commission, 09/10/2006. Online: http://ec.europa.eu/dgs/policy_advisers/ publications/docs/bepa_migration_final_09_10_006_en.pdf

Berend, I T, The History of European Integration. A New Perspective. London: Routledge, 2016. Online: https://doi.org/10.4324/9781315622903

Best, H, Gy Lengyel and L Verzichelli (eds), The Europe of Elites: A Study into the Europeanness of Europe's Political and Economic Elites. Oxford: Oxford University Press, 2012. Online: https://doi.org/10.1093/acprof:oso/9780199602315.001.0001

Blanchard, O, 'Concluding Remarks', in In the Wake of the Crisis. Leading Economists Reassess Economic Policy, ed. by O Blanchard, D Romer, M Spence and J Stiglith. Cambridge: MIT Press, 2012, 225-228. Online: https://doi.org/10.7551/mitpress/9451. 001.0001

Blanchard, O and D Leigh, 'Growth Forecast Errors and Fiscal Multipliers'. American Economic Review 103, no 3 (2013), 117-120. Online: https://doi.org/10.1257/aer.103.3. 117

Bølstad, J, 'Dynamics of European Integration: Public Opinion in the Core and Periphery’. European Union Politics 16, no 1 (2014), 23-44. Online: https://doi.org/10.11 77/1465116514551303

Bordo, M D, 'The United States as a Monetary Union and the Euro: A Historical Perspective'. Cato Journal 24, no 1-2 (2004), 163-170.

Bordo, M D, L Jonung and A Markiewicz, 'A Fiscal Union for the Euro: Some Lessons from History'. NBER Working Paper no 17380, 2011. Online: https://oi.org/10.3386/ w17380

Boulding, K E, A Reconstruction of Economics. New York: Wiley, 1950.

Brady, D M, 'Globalization and Political Instability. How the Transformation of the World Economy Shook Up Western Politics'. The American Interest 11, no 6 (2016).

Brennan, G and A Hamlin, 'The European Constitution and Peace: Taking the Heat out of Politics', in A Constitution for the European Union, ed. by C B Blankart and D Mueller. Cambridge: MIT Press, 2004, 3-23. 
Brooks, R, Bean Counters: The Triumph of the Accountants and How They Broke Capitalism. London: Atlantic Books, 2018.

Brynjolfsson, E, 'ICT, Innovation and the e-economy'. European Investment Bank, EIB Papers 16, no 2 (2011), 60-76.

Buti, M, S C W Eijffinger and D Franco, 'Revisiting the Stability and Growth Pact: Grand Design or Internal Adjustment?’ CEPR Discussion Papers no 3692, 2003.

Campos, N, F Coricelli and L Moretti, 'Economic Growth and Political Integration: Estimating the Benefits from Membership in the European Union Using the Synthetic Counterfactuals Method'. IZA Discussion Paper no 8162, 2014.

Campos, N and J E Sturm (eds), Bretton Woods, Brussels and Beyond: Redesigning the Institutions of Europe. CEPR Press, 2018.

Caselli, F, 'Discussion of Mongelli and Wyplosz', 2008. Online: www.ecb.int/events/pdf/ conferences/cbc5/Caselli.pdf

Chakrabarti, A S and A Sengupta, 'Economic Incentives versus Institutional Frictions: Explaining Cross-country Labour Immobility in the European Union', 2015. Online: www.dropbox.com/s/233sn00c89xwb8t/migr_ASC_AD.pdf?dl=0

Chandrappa, R and D B Das, Solid Waste Management. Principles and Practice. BerlinHeidelberg: Springer, 2012. Online: https://doi.org/10.1007/978-3-642-28681-0

Coibion, O, Y Gorodnichenko, M Kudlyak and J Mondragon, 'Does Greater Inequality Lead to More Household Borrowing? New Evidence from Household Data'. NBER Working Paper no 19850, 2014. Online: https://doi.org/10.3386/w19850

Council of Europe, Report by Nils Muiznieks. Commissioner for Human Rights of the Council of Europe. Following His Visit to Poland from 9 to 12 February 2016. Council of Europe, June 2016.

Cowen, T, The Great Stagnation: How America Ate All The Low-Hanging Fruit of Modern History, Got Sick, and Will (Eventually) Feel Better. Dutton, 2011.

Crafts, N, West European Economic Integration since 1950: Implications for Trade and Income. The University of Warwick, Working Paper No. 219, 2015.

Crafts, N and G Toniolo, 'Aggregate Growth, 1950-2005', in The Cambridge Economic History of Modern Europe: 1870 to the Present, Volume 2, ed. by S Broadberry and K H O’Rourke. Cambridge: Cambridge University Press, 2010, 296-332. Online: https:// doi.org/10.1017/cbo9780511794841.014

Csaba, L, 'A New Political Economy - For Development', in Management and Economic Policy for Development, ed. by G W Kołodko. New York: Nova Science Publishers, 2014, 239-250.

Csaba, L, 'A 21. század a világ közgazdaságtanában'. Köz-Gazdaság 13, no 2 (2018), 113-126. Online: https://doi.org/10.14267/retp2018.02.26

Deaton, A and O Dupriez, 'Purchasing Power Parity Exchange Rates for the Global Poor'. American Economic Journal: Applied Economics 3, no 2 (2011), 137-166. Online: https://doi.org/10.1257/app.3.2.137

De Neve, J-E, G W Ward, F De Keulenaer, B Van Landeghem, G Kavetsos and M I Norton, 'The Asymmetric Experience of Positive and Negative Economic Growth: Global Evidence Using Subjective Well-Being Data'. IZA Discussion Paper no 8914, 2015. Online: https://doi.org/10.2139/ssrn.2506600 
Di Meglio, G, M Stare, A Maroto and L Rubalcaba, 'Public Services Performance: An Extended Framework and Empirical Assessment Across the Enlarged EU'. Environment and Planning C: Politics and Space 33, no 2 (2015), 321-341. Online: https://doi. org/10.1068/c12264r

Dustmann, $C$ and T Frattini, 'The Fiscal Effects of Immigration to the UK'. CReAM Discussion Paper no 22, 2013. Online: https://doi.org/10.1111/ecoj.12181

ECRI, Annual Report on ECRI's Activities. Covering the Period from 1 January to 31 December 2015. Council of Europe, European Commission against Racism and Intolerance, 2016. Online: www.coe.int/t/dghl/monitoring/ecri/activities/Annual_Reports/Ann ual\%20report\%202015.pdf

EEA, 'Managing Municipal Solid Waste - A Review of Achievements in 32 European Countries'. European Environment Agency, EEA Report no 2, 2013. Online: https:// doi.org/10.2800/71424

Ederveen, S, H de Groot and R Nahuis, 'Fertile Soil for Structural Funds? A Panel Data Analysis of the Conditional Effectiveness of European Cohesion Policy'. Kyklos 59, no 1 (2006), 17-42. Online: https://doi.org/10.1111/j.1467-6435.2006.00318.x

Eggertsson, G B, N R Mehrotra, S R Singh and L H Summers, 'A Contagious Malady? Open Economy Dimensions of Secular Stagnation'. NBER Working Paper no 22299, 2016. Online: https://doi.org/10.3386/w22299

Eichengreen, B, 'Secular Stagnation - The Long View'. American Economic Review 105, no 5 (2015), 66-70. Online: https://doi.org/10.1257/aer.p20151104

Eichengreen, B and A Boltho, 'The Economic Impact of European Integration', in The Cambridge Economic History of Modern Europe: 1870 to the Present, Volume 2, ed. by S Broadberry and K H O’Rourke. Cambridge: Cambridge University Press, 2010, 267-295. Online: https://doi.org/10.1017/CBO9780511794841.013

Eucken, W, Die Grundlagen der Nationalökonomie. 9 $9^{\text {th }}$ edition. Berlin: Springer, 1989. Online: https://doi.org/10.1007/978-3-642-61337-1

Eucken, W, Grundsätze der Wirtschaftspolitik. $6^{\text {th }}$ edition. Tübingen: J. C. B. Mohr, 1990.

European Commission, Eurobarometer No. 34, Public Opinion in the European Community. Brussels: European Commission, December 1990.

European Commission, Employment in Europe 2010. Brussels: Employment, Social Affairs and Inclusion, 2010.

European Commission, 'Policies in Support of Service Innovation'. INNO-Grips Policy Brief no 3. Principal author: Olivér Kovács, ICEG European Center, European Commission, DG Growth, 2011.

European Commission, Powering European Public Sector Innovation: Towards A New Architecture. Report of the Expert Group on Public Sector Innovation, Directorate-General for Research and Innovation, 2013. Online: https://doi.org/10.2777/51054

European Commission, Stronger and Smarter Information Systems for Borders and Security. Brussels: European Commission, 6.4.2016. COM(2016) 205 final.

European Commission, Horizon 2020 Interim Evaluation: Maximising the Impact of EU Research and Innovation. European Commission, COM(2018) 2 final.

European Systemic Risk Board, 'Shedding Lights on Dark Markets. First Insights from the New EU-wide OTC Derivatives Dataset'. Occasional Paper Series no 11, 2016. Online: https://doi.org/10.2849/878675 
Eurostat, Smarter, Greener, More Inclusive? Indicators to Support the Europe2020 Strategy. Eurostat, Statistical Books, 2016. Online: https://doi.org/10.2785/101636

Eurostat, Europe 2020 Strategy. Positive Developments since 2008 in the EU on Education, Climate Change and Energy... but Limited or No Progress for Employment, Poverty and $R \& D$. Eurostat, News release, 19 July 2016.

Fischer, J, L Jonung and M Larch, '101 Proposals to Reform the Stability and Growth Pact. Why So Many? A Survey'. European Commission, Economic Papers no 267, 2006.

Foged, M and G Peri, 'Immigrants' Effect on Native Workers: New Analysis on Longitudinal Data'. IZA Discussion Paper no 8961, 2015.

Fratzscher, M, Verteilungskampf. Warum Deutschland immer ungleicher wird. Hanser Verlag, 2016. Online: https://doi.org/10.3139/9783446444669

Freire, P, Pedagogy of the Oppressed. New York: Continuum, 1970.

Freund, C and S Oliver, 'The Origins of the Superrich: The Billionaire Characteristics Database'. Peterson Institute for International Economics, Working Paper no 16-1, 2016. Online: https://doi.org/10.2139/ssrn.2731353

Friedel, J. 'Lessons for the Euro from Early American Monetary and Financial History'. Bruegel Essay and Lecture Series, 2016. Online: http://bruegel.org/wp-content/ uploads/2016/05/essay_frieden_may16.pdf

Friedman, M, Essays in Positive Economics. University of Chicago Press, 1953.

Friedman, M, 'Containing Spending'. Society 14, no 3 (1977), 89-92. Online: https://doi. org/10.1007/BF02694452

Galtung, J, 'The Structural Theory of Imperialism'. Journal of Peace Research 8, no 2 (1971), 81-117. Online: https://doi.org/10.1177/002234337100800201

Gennaioli, N, A Shleifer and R Vishny, 'Neglected Risks: The Psychology of Financial Crises'. American Economic Review 105, no 5 (2015), 310-314. Online: https://doi. org/10.1257/aer.p20151091

Gennaioli, N, Y Ma and A Shleifer, 'Expectations and Investment', NBER Working Paper Series no 21260, 2015. Online: https://doi.org/10.3386/w21260

German Council of Economic Experts, Annual Economic Report 2013/14. Online: www. sachverstaendigenrat-wirtschaft.de/fileadmin/dateiablage/download/gutachten/ executive_summary_2013.pdf

Glushko, R J, 'Designing a Service Science Discipline with Discipline'. IBM Systems Journal 47, no 1 (2008), 15-27. Online: https://doi.org/10.1147/sj.471.0015

Giddens, A, The Consequences of Modernity. Stanford, CA: Stanford University Press, 1990.

Gordon, R J, 'Is US Economic Growth Over? Faltering Innovation Confronts the Six Headwinds'. CEPR Policy Insight no 63, 2012. Online: https://doi.org/10.3386/w18315

Gorodnichenko, Y and G Roland, 'Understanding the Individualism-Collectivism Cleavage and its Effects: Lessons from Cultural Psychology', in Institutions and Comparative Economic Development, ed. by M Aoki, T Kuran and G Roland. London: Palgrave Macmillan, International Economic Association Series, 2012, 213-236. Online: https://doi.org/10.1057/9781137034014_12

Guiso, L, H Herrera and M Morelli, 'Cultural Differences and Institutional Integration'. Journal of International Economics 99, 2016, 97-113. Online: https://doi.org/10. 1016/j.jinteco.2015.11.005 
Gutiérrez-Romero, R, D Haubrich and I McLean, 'The Limits of Performance Assessments of Public Bodies: External Constraints in English Local Government'. Environment and Planning C: Politics and Space 26, no 4 (2008), 767-787. Online: https:// doi.org/10.1068/c0661

Halmai, P, “Új geometria: „teljes” gazdasági és monetáris unió? A gazdasági kormányzás új dimenziói az Európai Unióban'. Magyar Tudomány 178, no 1 (2017), 6-17.

Hart, A, 'Risk, Uncertainty, and Unprofitability of Compounding Probabilities', in Studies in Mathematical Economics and Econometrics, ed. by O Lange, F McIntyre and T O Yntema. Chicago: University of Chicago Press, 1942, 110-118.

Haskel, J and S Westlake, Capitalism without Capital. The Rise of the Intangible Economy. Princeton \& Oxford: Princeton University Press, 2018. Online: https://doi.org/10. 1515/9781400888320

Heipertz, M and A Verdun, Ruling Europe - The Politics of the Stability and Growth Pact. Cambridge: Cambridge University Press, 2010. Online: https://doi.org/10.1017/ CBO9780511750380

Hossein-zadeh, I, Beyond Mainstream Explanations of the Financial Crisis. Parasitic Finance Capital. London: Routledge, Routledge Frontiers of Political Economy, 2014. Online: https://doi.org/10.4324/9780203084199

IOM, Migration, Environment and Climate Change: Assessing the Evidence. International Organisation for Migration, 2009. Online: http://publications.iom.int/system/ files/pdf/migration_and_environment.pdf

IPCC, Climate Change 2007: Working Group III: Mitigation of Climate Change. 10.2 Status of the Waste Management Sector, 2007. Online: www.ipcc.ch/publications_and_data/ ar4/wg3/en/ch10s10-2.html

Jacomella, G, Media and Migrations: Press Narrative and Country Politics in Three European Countries. Reuters Institute Fellow's Paper, University of Oxford, 2010.

Jonung, L and E Drea, 'The Euro: It Can't Happen. It's a Bad Idea. It Won't Last. US Economists on the EMU, 1989-2002'. European Economy, Economic Papers no 395, 2009.

Juncker, J-C, State of the Union 2015: Time for Honesty, Unity and Solidarity. European Commission - Speech. Strasbourg, 9 September 2015. Online: http://europa.eu/ rapid/press-release_SPEECH-15-5614_en.htm

Kahneman, D and A Tversky, 'Prospect Theory: An Analysis of Decision under Risk'. Econometrica 47, no 2 (1979), 263-291. Online: https://doi.org/10.2307/1914185

Knight, F H, Risk, Uncertainty and Profit. New York: Harper, 1921.

Kondratieff, N D, 'The Long Waves in Economic Life'. The Review of Economic Statistics 17, no 6 (1935), 105-115. Online: https://doi.org/10.2307/1928486

Kornai, J, 'Hungary's U-turn'. Society and Economy 37, no 3 (2015), 279-329. Online: https://doi.org/10.1556/204.2015.37.3.1

Kovács, O, 'Policies Supporting Innovation in Public Service Provision'. INNO-Grips Policy Brief no 5, 2012.

Kovács, O, Stabilitás és dinamizmus. Az innovatív fiskális politika alapjai [Stability and Dynamism. The Fundamentals of Innovative Fiscal Policy]. Budapest: Alinea, 2015. Online: http://dx.doi.org/10.18414/Ksz.2015.11.1211 
Kovács, O, 'The Hungarian Agony over Eurozone Accession', in Core-periphery Relations in the European Union - Power and Conflict in a Dualist Political Economy, ed. by J M Magone, B Laffan and C Schweiger. Routledge, 2016, 231-250.

Kovács, O, 'The Complexity of the European Integration - The General Vectors of Disorientegration'. Európai Tükör 21, Special Edition (2018), 29-47.

Kovács, O, 'Grounding Complexity Economics in Framing Modern Governance'. Acta Oeconomica 69, no 4 (2018), 571-594. Online: https://doi.org/10.1556/032.2019.69.4.5

Lanham, R A, The Economics of Attention. Style and Substance in the Age of Information. Chicago: University of Chicago Press, 2006.

Li, K K, 'Asymmetric Memory Recall of Positive and Negative Events in Social Interactions'. Experimental Economics 16, no 3 (2012), 248-262. Online: https://doi. org/10.1007/s10683-012-9325-9

Liargovas, P, S Petropoulos, N Tzifakis and A Huliaras, Beyond "Absorption": The Impact of EU Structural Funds on Greece. Konrad Adenauer Stiftung, 2015.

Lundvall, B A, 'The University in the Learning Economy'. DRUID Working Paper no 6, 2002.

Magone, J M, B Laffan and C Schweiger (eds), Core-periphery Relations in the European Union - Power and Conflict in a Dualist Political Economy. Routledge, 2016. Online: https://doi.org/10.4324/9781315712994

Mandel, M, Beyond Goods and Services: The (Unmeasured) rise of the Data-Driven Economy. Progressive Policy Institute, Policy Memo, October 2012.

McCloskey, D N, Bourgeois Equality. How Ideas, Not Capital or Institutions, Enriched the World. Chicago: University of Chicago Press, 2016.

Mian, A R, A Sufi and E Verner, 'Household Debt and Business Cycles Worldwide'. NBER Working Paper no 21581, 2015. Online: https://doi.org/10.3386/w21581

Mises, L von, A Critique of Interventionism. Irvington-on-Hudson, New York: Foundation for Economic Education, 1996.

Mises, L von, Human Action - A Treatise on Economics. New Haven: Yale University Press, 1949.

Mokyr, J, 'Secular Stagnation? Not in Your Life', in Secular Stagnation: Facts, Causes, and Cures, ed. by C Teulings and R Baldwin. CEPR Press, 2014, 83-90.

Monperrus-Veroni, P and F Saraceno, 'Reform of the Stability and Growth Pact: Reducing or Increasing the Nuisance?' Documents de Travail de l'OFCE no 1, 2005.

Moran, M and D Waddington, 'France in Flames: The French Riots of 2005', in Riots. An International Comparison, ed. by M Moran and D Waddington. Palgrave Macmillan - Springer, 2016, 39-65. Online: https://doi.org/10.1057/978-1-137-57131-1_3

Muschg, A, Was ist europäisch? Reden für einen gastlichen Erdteil. München: C. H. Beck, 2005.

Musto, S A, 'Information als Kulturphänomen und Machtressource', in Mikroelektronik: die Folgen für die zwischenmenschliche Kommunikation. Institut für Gesellschafts- und Wirtschaftskommunikation, ed. by T Borbé. Berlin: Colloquium Verlag, 1984.

Neiman, B, 'The Global Decline of the Labor Share'. The Quarterly Journal of Economics 129, no 1 (2013), 61-103. Online: https://doi.org/10.1093/qje/qjt032

Európai Tükör 2021/1. 
Nölke, A, 'Economic Causes of the Eurozone Crisis: The Analytical Contribution of Comparative Capitalism'. Socio-Economic Review 14, no 1 (2016), 141-161. Online: https://doi.org/10.1093/ser/mwv031

OECD, 'Is Convergence a Spontaneous Process? The Experience of Spain, Portugal and Greece'. OECD Economic Studies no 16, Spring 1991.

Packalen, M and J Bhattacharya, 'New Ideas in Invention'. NBER Working Paper no 20922, 2015. Online: https://doi.org/10.3386/w20922

Perez, C, Technological Revolutions and Financial Capital: The Dynamics of Bubbles and Golden Ages. Cheltenham: Elgar, 2002. Online: https://doi.org/10.4337/9781781005323

Perez, C, 'Technological Revolutions and Techno-Economic Paradigms'. TOC/TUT Working Paper no 20, 2009.

Portes, J, Migrants, Benefits and the UK's Renegotiation: Questions and Answers. National Institute of Economic and Social Research, United Kingdom, 2015. Online: www. niesr.ac.uk/blog/migrants-benefits-and-uks-renegotiation-questions-and-answers -updated\#.V4NPSaIQPpG

Prigogine, I, 'Time, Structure and Fluctuations'. Nobel Lecture, 8 December 1977. Online: https://doi.org/10.1126/science.201.4358.777

Prigogine, I, From Being to Becoming: Time and Complexity in the Physical Sciences. San Francisco: W.H. Freeman, 1980.

Prigogine, I, The End of Certainty. Time, Chaos, and the New Laws of Nature. New York: Free Press, 1997.

Rennstich, J K, 'The New Economy, the Leadership Long Cycle and the Nineteenth K-wave'. Review of International Political Economy 9, no 1 (2002), 150-182. Online: https://doi.org/10.1080/09692290110101135

Reinfeldt, A, 'Communicating European Integration - Information vs. Integration?' Journal of Contemporary European Research 10, no 1, (2014), 44-56.

Röpke, W, 'Europa als wirtschaftliche Aufgabe', in Europa - Besinnung und Hoffnung, ed. by A Hunold. Zürich: Erlenbach, 1957, 159-184.

Sachs, J, 'Why ISIS Persists'. Project-Syndicate, 5 July 2016.

Santos, T D, 'The Structure of Dependence', in Readings in U.S. Imperialism, ed. by K T Fann and D C Hodges. Boston: Porter Sargent, 1971.

Sapir, A, P Aghion, G Bertola, M Hellwig, J Pisani-Ferry, D Rosati, J Vinals and H Wallace, An Agenda for a Growing Europe. Oxford: Oxford University Press, 2004. Online: https://doi.org/10.1093/0199271488.001.0001

Schimmelfennig, $\mathrm{F}$ and $\mathrm{T}$ Winzen, 'Explaining Differentiation in European Union Treaties'. European Union Politics 17, no 4 (2016). Online: https://doi.org/10.1177/ 1465116516640386

Schulz, M and T A Schwartz, 'The Superpower and the Union in the Making: US-European Relations, 1969-1980', in The Strained Alliance: US-European Relations from Nixon to Carter, ed. by M Schulz and T A Schwartz. Cambridge: Cambridge University Press, 2010, 355-374.

Seers, D, 'What Are We Trying to Measure?' Journal of Development Studies 8, no 3 (1972), 21-36. Online: https://doi.org/10.1080/00220387208421410

Seers, D, B Schaffer and M-L Kiljunen (eds), Underdeveloped Europe: Studies in the European Periphery. Branch Line, Humanities Press, 1979. 
Seers, D and C V Vaitsos (eds), Integration and Unequal Development. The Experience of the EEC. Palgrave Macmillan UK, 1980. Online: https://doi.org/10.1007/978-1-34905538-8

Seers, D, 'Introduction: The Second Enlargement in Historical Perspective', in The Second Enlargement of the EEC - Integration of Unequal Partners, ed. by D Seers and C V Vaitsos. Palgrave Macmillan, 1982, 6-7. Online: https://doi.org/10.1007/978-1349-16760-9

Seers, D and C V Vaitsos, The Second Enlargement of the EEC - Integration of Unequal Partners. Palgrave Macmillan UK, 1982. Online: https://doi.org/10.1007/978-1349-16760-9

Sen, A, The Idea of Justice. London: Penguin Books, 2010. Online: https://doi.org/10.2307 /j.ctvjnrv7n

Sen, A and M Nussbaum (eds), The Quality of Life. Revised edition, Gloucestershire: Clarendon Press, 1993. Online: https://doi.org/10.1093/0198287976.001.0001

Shiller, R J, Finance and the Good Society. Princeton: Princeton University Press, 2012.

Shiller, R J, 'The Best, Brightest, and Least Productive?' World Economic Forum, 20 September 2013.

Snower, D J and S J Bosworth, 'Identity-driven Cooperation versus Competition'. The American Economic Review 106, no 5 (2016), 420-424. Online: https://doi.org/10. 1257/aer.p20161041

Spence, M and D W Brady, 'Economics in a Time of Political Instability'. Project Syndicate, 23 March 2016.

Spiegel, 'European Luminaries Reflect on Euro: 'Seventeen Countries Were Far Too Many’.' Interview, Spiegel.de, 11 September 2012. Online: www.spiegel.de/international/europe/spiegel-interview-with-helmut-schmidt-and-valery-giscard-d-estaing-a-855127.html

Spolaore, E, 'What is European Integration Really About? A Political Guide for Economists'. Journal of Economic Perspectives 27, no 3 (2013), 125-144. Online: https:/doi. org/10.1257/jep.27.3.125

Spolaore, E and R Wacziarg, 'How Deep Are the Roots of Economic Development?' Journal of Economic Literature 51, no 2 (2013), 325-369. Online: https://doi.org/10.1257/ jel.51.2.325

Teulings, C and R Baldwin (eds), Secular Stagnation: Facts, Causes and Cures. CEPR Press, 2014.

Temin, P and D Vines, The Leaderless Economy: Why the World Economic System Fell Apart and How to Fix It. Princeton: Princeton University Press, 2013. Online: https://doi. org/10.1515/9781400846641

Tóth, G, 'The Forecasting Capacity of Indicators Measuring Budget Sustainability'. Public Finance Quarterly no 4 (2014), 511-528.

Verheugen, G, European Integration is not About Changing the Past but About Shaping the Future. SPEECH/02/147, Charles University, Faculty of Social Sciences, Prague, 11 April 2002.

Wickens, M, Avoiding another Eurozone Crisis while avoiding the Five Presidents' Report: Part I. CEPR Press, 2016. Online: http://voxeu.org/article/avoiding-another-eurozone-crisis-part-i 
World Inequality Lab, World Inequality Report 2018. Online: http://wir2018.wid.world/ files/download/wir2018-full-report-english.pdf

Wyplosz, C, The Stability Pact Meets Its Fate. Paper prepared for the 'Euro 50 Group' Meeting, 27 November 2002.

Zipfel, F, S Vetter and D Pietzker, Better Off On Their Own? Economic Aspects of Regional Autonomy and Independence Movements in Europe. DB Research, EU Monitor European Integration, 2015. Online: www.dbresearch.com/PROD/DBR_INTER NET_EN-PROD/PROD0000000000350394/Better_off_on_their_own\%3F_Economic_aspects_of_regio.pdf 